\title{
Interaction of Unvented Attics With Living Space in Three Northeast Homes
}

Srikanth Puttagunta and Omari Faakye Consortium for Advanced Residential Buildings 


\title{
NOTICE
}

This report was prepared as an account of work sponsored by an agency of the United States government. Neither the United States government nor any agency thereof, nor any of their employees, subcontractors, or affiliated partners makes any warranty, express or implied, or assumes any legal liability or responsibility for the accuracy, completeness, or usefulness of any information, apparatus, product, or process disclosed, or represents that its use would not infringe privately owned rights. Reference herein to any specific commercial product, process, or service by trade name, trademark, manufacturer, or otherwise does not necessarily constitute or imply its endorsement, recommendation, or favoring by the United States government or any agency thereof. The views and opinions of authors expressed herein do not necessarily state or reflect those of the United States government or any agency thereof.

Available electronically at http://www.osti.gov/bridge

Available for a processing fee to U.S. Department of Energy and its contractors, in paper, from:

\author{
U.S. Department of Energy \\ Office of Scientific and Technical Information \\ P.O. Box 62 \\ Oak Ridge, TN 37831-0062 \\ phone: 865.576 .8401 \\ fax: 865.576.5728 \\ email: mailto:reports@adonis.osti.gov
}

Available for sale to the public, in paper, from:

U.S. Department of Commerce

National Technical Information Service

5285 Port Royal Road

Springfield, VA 22161

phone: 800.553 .6847

fax: 703.605.6900

email: orders@ntis.fedworld.gov

online ordering: http://www.ntis.gov/ordering.htm 


\title{
Interaction of Unvented Attics With Living Space in Three Northeast Homes
}

\author{
Prepared for: \\ The National Renewable Energy Laboratory \\ On behalf of the U.S. Department of Energy's Building America Program \\ Office of Energy Efficiency and Renewable Energy \\ 15013 Denver West Parkway \\ Golden, CO 80401 \\ NREL Contract No. DE-AC36-08GO28308
}

Prepared by:

Srikanth Puttagunta and Omari Faakye

Steven Winter Associates, Inc.

of the

Consortium for Advanced Residential Buildings (CARB)

61 Washington Street

Norwalk, CT 06854

NREL Technical Monitor: Stacey Rothgeb

Prepared under Subcontract No. KNDJ-0-40342-05

February 2015 
The work presented in this report does not represent performance of any product relative to regulated minimum efficiency requirements.

The laboratory and/or field sites used for this work are not certified rating test facilities. The conditions and methods under which products were characterized for this work differ from standard rating conditions, as described.

Because the methods and conditions differ, the reported results are not comparable to rated product performance and should only be used to estimate performance under the measured conditions. 


\section{Contents}

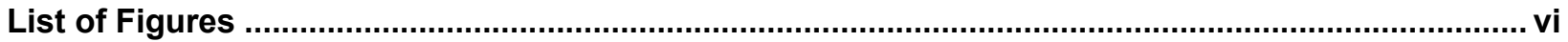

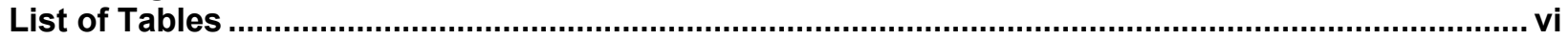

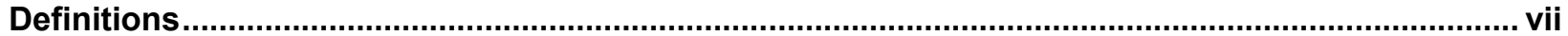

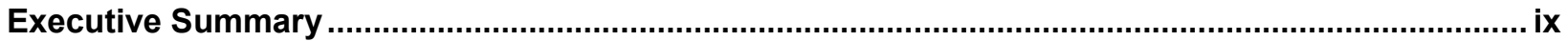

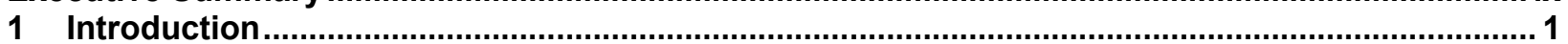

1.1 Relevance to Building America's Goals ........................................................................ 1

1.2 Modeling Interior and Attic Temperature ...........................................................

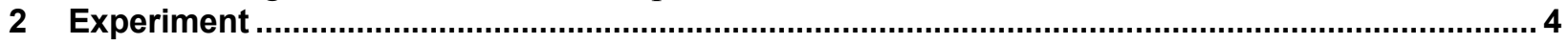

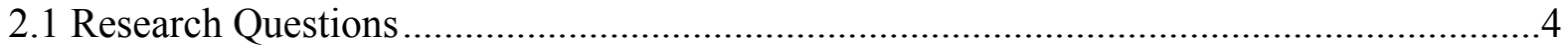

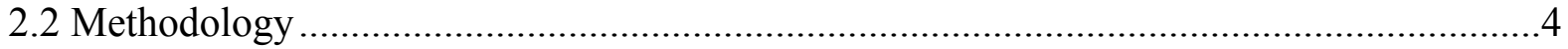

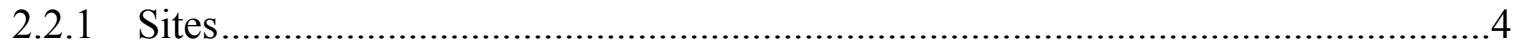

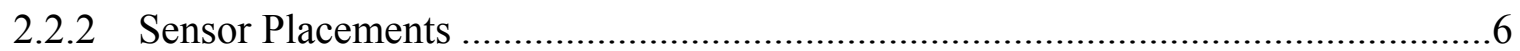

2.2.3 Characterization of Test Sites - Building Leakage Testing ................................. 10

2.2.4 Characterization of Test Sites - Duct Leakage Testing ......................................13

2.2.5 Characterization of Test Sites - Solar Irradiance ...............................................13

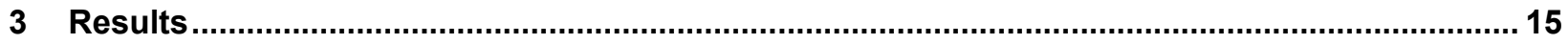

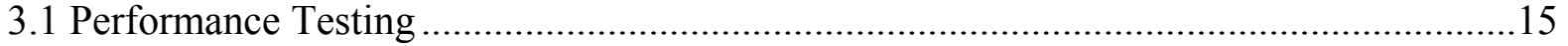

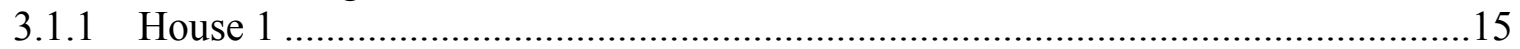

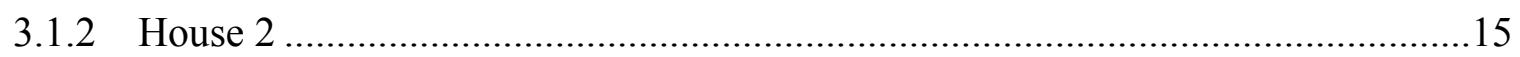

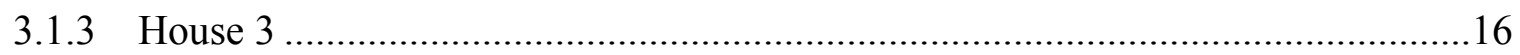

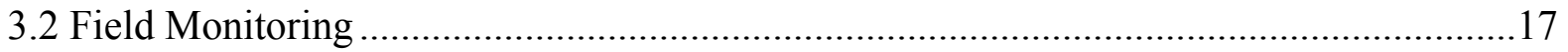

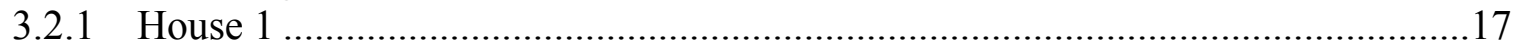

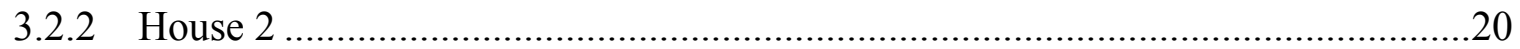

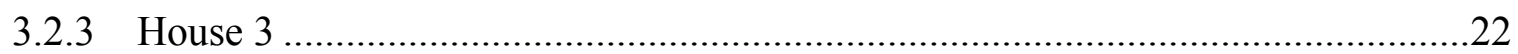

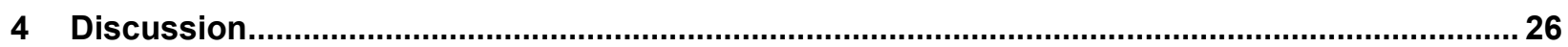

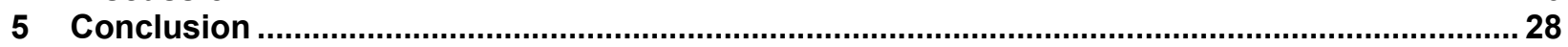

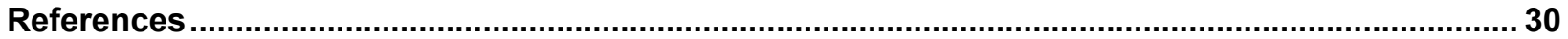




\section{List of Figures}

Figure 1. Average indoor and attic temperature for vented and unvented attics ............................ 2

Figure 2. Average indoor and attic humidity ratio for vented and unvented attics .......................... 3

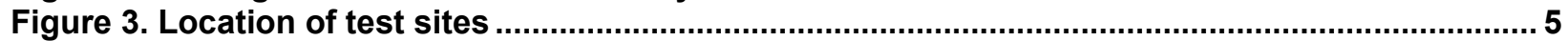

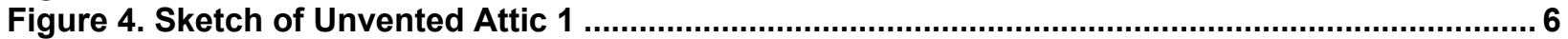

Figure 5. Sketch of Unvented Attic 2 ........................................................................................ 6

Figure 6. Temperature differences between sensor at $\mathrm{CM}$ and sensors at other positions in

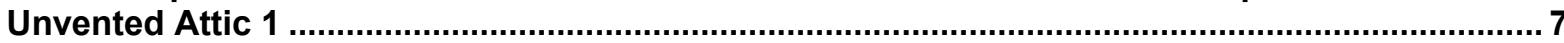

Figure 7. Humidity ratio differences between sensor at $C M$ and sensors at other positions in

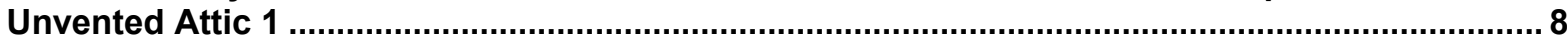

Figure 8. Temperature differences between sensor at $\mathrm{CM}$ and sensors at other positions in

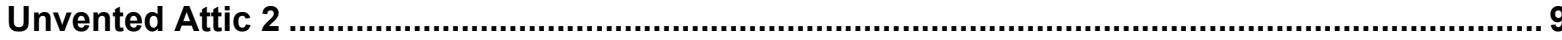

Figure 9. Humidity ratio differences between sensor at $\mathrm{CM}$ and sensors at other positions in

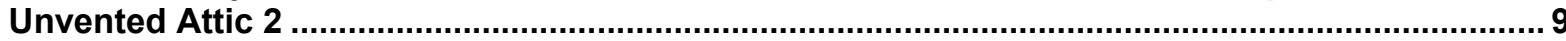

Figure 10. Humidity ratio at the CM and LT sensors, in the living space, and outdoors at House 2 for a typical summer week.

Figure 11. Depressurization test with unvented attic hatch open. ................................................ 11

Figure 12. Depressurization test with unvented attic hatch closed. ................................................ 11

Figure 13. Depressurization test with unvented attic hatch carefully sealed.................................... 12

Figure 14. Depressurization test of house and attic. The attic depressurization flow rate minus the difference between blower door cfm50 with the attic hatch open and closed is the leakage of just the unvented attic.

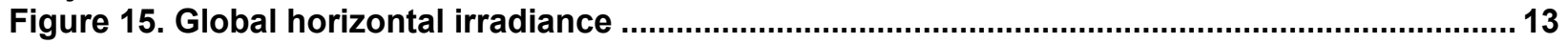

Figure 16. Summer impact of solar irradiance on Unvented Attic 1............................................... 14

Figure 17. Temperature conditions at House 1 .............................................................................. 18

Figure 18. House 1 temperature differential with respect to outdoor temperature.......................... 18

Figure 19. Humidity conditions at House 1 .................................................................................. 19

Figure 20. House 1 humidity ratio differential with respect to outdoor humidity ratio ..................... 19

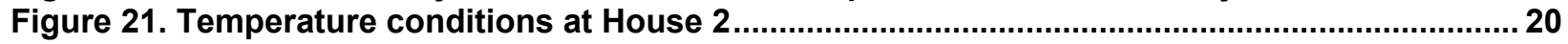

Figure 22. House 2 temperature differential with respect to outdoor temperature...........................21

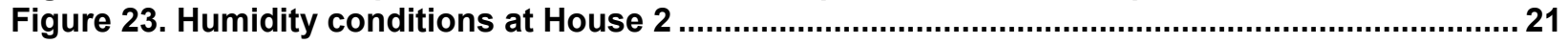

Figure 24. House 2 humidity ratio differential with respect to outdoor humidity ratio ......................22

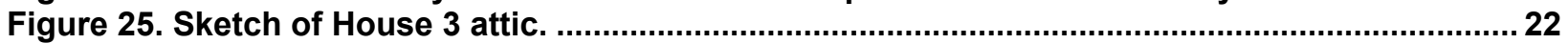

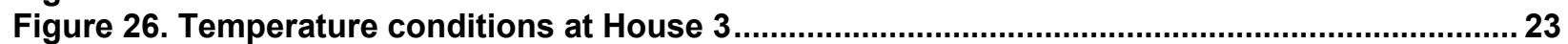

Figure 27. House 3 temperature differential with respect to outdoor temperature............................24

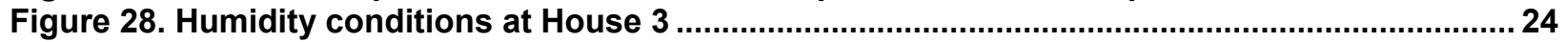

Figure 29. House 3 humidity ratio differential with respect to outdoor humidity ratio .....................25

Figure 30. Temperature trend lines for the three test homes and a BEopt model ..........................26

Figure 31. Humidity trend lines for the three test homes and a BEopt model .................................. 26

Unless otherwise noted, all figures were created by CARB. 


\section{List of Tables}

Table 1. Temperature and Humidity Ratio Trends for Various House Types .................................... ix

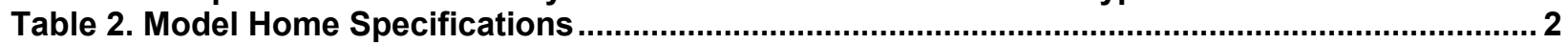

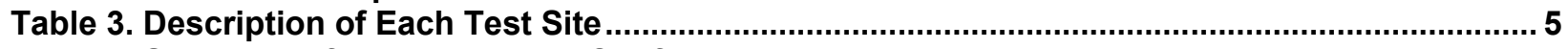

Table 4. Summary of Unvented Attic Configurations.................................................................. 5

Table 5. Average Temperature and Humidity Ratio Difference Between Centrally Placed Sensor and Other Sensors Placed All Around the Unvented Attic Space Over Winter and Spring ......... 7

Table 6. Whole-Building Depressurization Test Results at House 1 .............................................15

Table 7. Whole-Building Depressurization Test Results at House 2 ................................................ 16

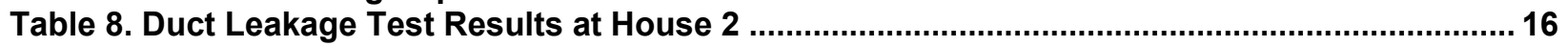

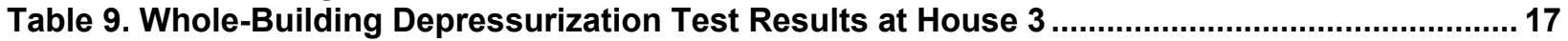

Table 10. Temperature and Humidity Ratio Trends for Various House Types .................................. 27

Table 11. Temperature and Humidity Ratio Trends for Various House Types ............................... 28

Unless otherwise noted, all tables were created by CARB. 


\section{Definitions}

ACH50

BEopt $^{\mathrm{TM}}$

CARB

ccSPF

$\mathrm{cfm}$

ocSPF

ORNL

RH
Air Changes per Hour at 50 Pascal

Building Energy Optimization software

Consortium for Advanced Residential Buildings

Closed-cell spray polyurethane foam

Cubic feet per minute

Open-cell spray polyurethane foam

Oak Ridge National Laboratory

Relative humidity 


\section{Executive Summary}

Unvented roof assemblies are becoming common in North American construction. It is estimated that more than 100,000 have been constructed since 1995 (Schumacher 2007). According to Residential Energy Consumption Survey 2009 data, more than 30\% of homes with attics (about 10.4 million housing units) are located in the very cold/cold climate areas. The magnitude of these numbers for the potential of unvented attic retrofits emphasizes the significance of properly understanding how the attic conditions vary with respect to the conditioned space below.

Oak Ridge National Laboratory (ORNL) is being funded by the U.S. Department of Energy to conduct hygrothermal envelope modeling to predict the sheathing moisture for various unvented attic conditions in different climate zones. This analysis will help to identify risks associated with installing spray foam under roof decks. Presently, only living space temperature and relative humidity conditions are used in the modeling tool; these are assumed to be the same for the living and attic spaces. An initial study by ORNL in the mixed-humid climate suggested this is not a correct assumption, so ORNL requested field measurements of attic conditions and various other parameters that may influence the attic conditions in three varying unvented attic configurations in the cold climate region. These data will be used to validate ORNL's modeling methodologies and results.

To support this research, the Consortium for Advanced Residential Buildings (CARB), a DOE Building America research team led by Steven Winter Associates, Inc., gathered cold climate field measurement data for model validation and in support of design guidelines for constructing efficient, durable unvented roof assemblies. Data analysis of three test homes suggests that duct leakage and building infiltration have the greatest impact on the difference between the unvented attic and the conditioned living space conditions. If the unvented attic received indirect space conditioning from supply-side duct leakage, the attic temperature conditions tracked closer to the living space. Trends in the humidity ratio didn't seem to be significantly impacted by supply-side duct leakage. Also, the building leakage of the living space (all unvented attics were reasonably tight) resulted in variations in the humidity ratio trends; the leakier test home had much higher humidity ratios starting in the spring months. The other two tighter homes did not show signs of higher humidity ratios in the unvented attics, with respect to the living space, until the summer months. While this is only a small sample, based on this initial field monitoring, the equations in Table 1 are suggested for estimating attic conditions in the Northeast.

Table 1. Temperature and Humidity Ratio Trends for Various House Types

\begin{tabular}{c|c|c}
\hline House Type & $\begin{array}{c}\text { Unvented Attic Temperature } \\
\left({ }^{\circ} \mathbf{F}\right)\end{array}$ & $\begin{array}{c}\text { Unvented Attic Humidity } \\
\text { Ratio (lbw/lbda) }\end{array}$ \\
\hline $\begin{array}{c}\text { Energy-Efficient Home With Ducts in } \\
\text { Unvented Attic (Supply-Side Leakage) }\end{array}$ & $\mathrm{T}_{\mathrm{L}}+0.0009\left(\mathrm{~T}_{\mathrm{OA}}\right)^{2}-0.0508\left(\mathrm{~T}_{\mathrm{OA}}\right)$ & $\mathrm{HR}_{\mathrm{L}}+14.606\left(\mathrm{HR}_{\mathrm{OA}}\right)^{2}-$ \\
Energy-Efficient Home Without Ducts in & -0.1281 & $0.1424\left(\mathrm{HR}_{\mathrm{OA}}\right)+0.00005$ \\
Unvented Attic & $\mathrm{T}_{\mathrm{L}}+0.0007\left(\mathrm{~T}_{\mathrm{OA}}\right)^{2}+0.0751\left(\mathrm{~T}_{\mathrm{OA}}\right)$ & -7.5243 \\
Existing Cape Style Home With Only an & $\mathrm{T}_{\mathrm{L}}+0.0026\left(\mathrm{~T}_{\mathrm{OA}}\right)^{2}-0.005\left(\mathrm{~T}_{\mathrm{OA}}\right)$ & $\mathrm{HR}_{\mathrm{L}}+12.062\left(\mathrm{HR}_{\mathrm{OA}}\right)^{2}+$ \\
Unvented Attic Upgrade and No Ducts in & -7.2737 & $0.1192\left(\mathrm{HR}_{\mathrm{OA}}\right)-0.0002$ \\
\hline Attic & & \\
\hline
\end{tabular}

* variables: $\mathrm{T}=$ temperature, $\mathrm{HR}=$ humidity ratio

* subscripts: $\mathrm{L}=$ living space, $\mathrm{OA}=$ outdoor air 


\section{Introduction}

Oak Ridge National Laboratory (ORNL) is being funded by the U.S. Department of Energy (DOE) to conduct hygrothermal envelope modeling to predict the sheathing moisture for various unvented attic conditions in different climate zones. This analysis will help to identify risks associated with installing spray foam under roof decks. To generalize this approach for all U.S. climate zones, an enhanced model to predict attic conditions depending on climate zone; heating, ventilation, and air-conditioning (HVAC) system type; duct leakage; air and vapor tightness of the attic floor; etc. must be developed and validated. Presently, only living space temperature and relative humidity $(\mathrm{RH})$ conditions are used in the modeling tools. The software assumes that conditions are the same for the attic space, but that assumption is likely not accurate. Thus, to verify or disprove this assumption, field measurements of attic conditions and various other parameters that may influence the attic conditions are needed.

The potential for condensation is of particular concern with unvented attic roof systems in International Energy Conservation Code climate regions 5A and 6A. As such, the Consortium for Advanced Residential Buildings (CARB), a DOE Building America research team led by Steven Winter Associates, Inc., focused its research efforts on the cold climate field measurement data needed by ORNL for model validation and in support of design guidelines for constructing efficient, durable unvented roof assemblies.

\subsection{Relevance to Building America's Goals}

Unvented roof assemblies are becoming common in North American construction. It is estimated that more than 100,000 have been constructed since 1995 (Schumacher 2007). According to Residential Energy Consumption Survey 2009 data, more than 30\% of homes with attics (about 10.4 million housing units) are located in the very cold/cold climate areas. The magnitude of these numbers for the potential of unvented attic retrofits emphasizes the significance of properly modeling unvented attics. Understanding how the attic conditions vary throughout a heating season, and what they are relative to the conditioned space below, is important to verify modeling assumptions about attic conditions and improve the predictions of hygrothermal modeling studies. This ongoing research effort should have a significant impact in accurately modeling the potential energy savings of converting to an unvented attic for the millions of housing units that have vented attics in the very cold/cold climate areas.

\subsection{Modeling Interior and Attic Temperature}

To investigate the difference between vented and unvented attic conditions, the hourly temperature and RH estimates were plotted for a typical, moderately efficient $2,400-\mathrm{ft}^{2}$ house (building specifications provided in Table 2). The model was done in BEopt ${ }^{\mathrm{TM}}$ (Building Energy Optimization) version 2.1.0.0, software that provides capabilities to evaluate residential building designs and identify cost-optimal efficiency packages at various levels of whole-house energy savings along the path to zero net energy. 
Table 2. Model Home Specifications

\begin{tabular}{|c|c|}
\hline Options Category & Options Description \\
\hline Walls & R-13 blown cellulose, Gr-1, $2 \times 4,16$ in o.c. \\
\hline Wall Sheathing & Oriented strand board, R-5 extruded polystyrene \\
\hline Foundation & R10 perimeter \\
\hline Windows & Double-pane, low-e, insulated frame, argon filled \\
Roof/Ceiling & $\mathrm{U}=0.34$, solar heat gain coefficient $=0.30$ \\
\hline Air Leakages & R-49 \\
\hline Ventilation & $5.0 \mathrm{ACH}_{50}, 0.5$ shelter coefficient \\
\hline Appliances & Exhaust only, $100 \%$ ASHRAE 62.2 \\
\hline Lighting & Benchmark* \\
\hline $\begin{array}{c}\text { Cooling System } \\
\text { Heating System }\end{array}$ & Benchmark* \\
\hline Ducts & Gas furnace, $92.5 \%$ annual fuel utilization efficiency \\
\hline Water Heater & $7.5 \%$ leakage, R- 8 \\
\hline
\end{tabular}

* See Metzger et al. (2012) for details of the benchmark for each category.

Figure 1 shows the difference in the temperature estimates for each type of attic, as well as indoor temperature. The indoor temperatures in each house were very similar; therefore, the average was calculated. Figure 2 shows estimates of indoor and attic humidity ratios. Despite the difference between vented and unvented attic humidity ratio values, they follow a similar path. While the primary focus of this field monitoring is to provide data in support of ORNL's modeling efforts on unvented attics, CARB provides a comparison of these temperature and humidity ratio estimates to trends in the measured data in Section 4.

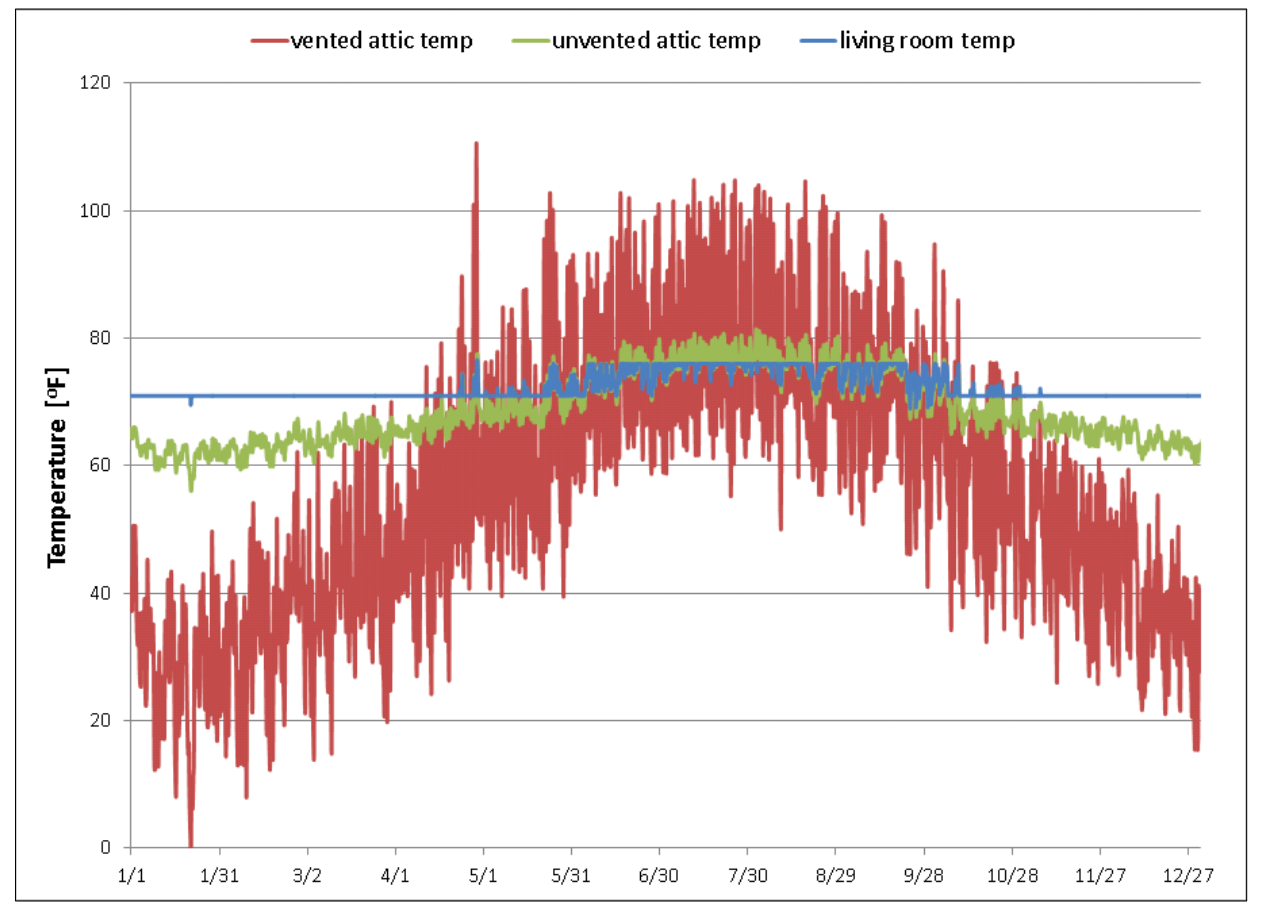

Figure 1. Average indoor and attic temperature for vented and unvented attics 


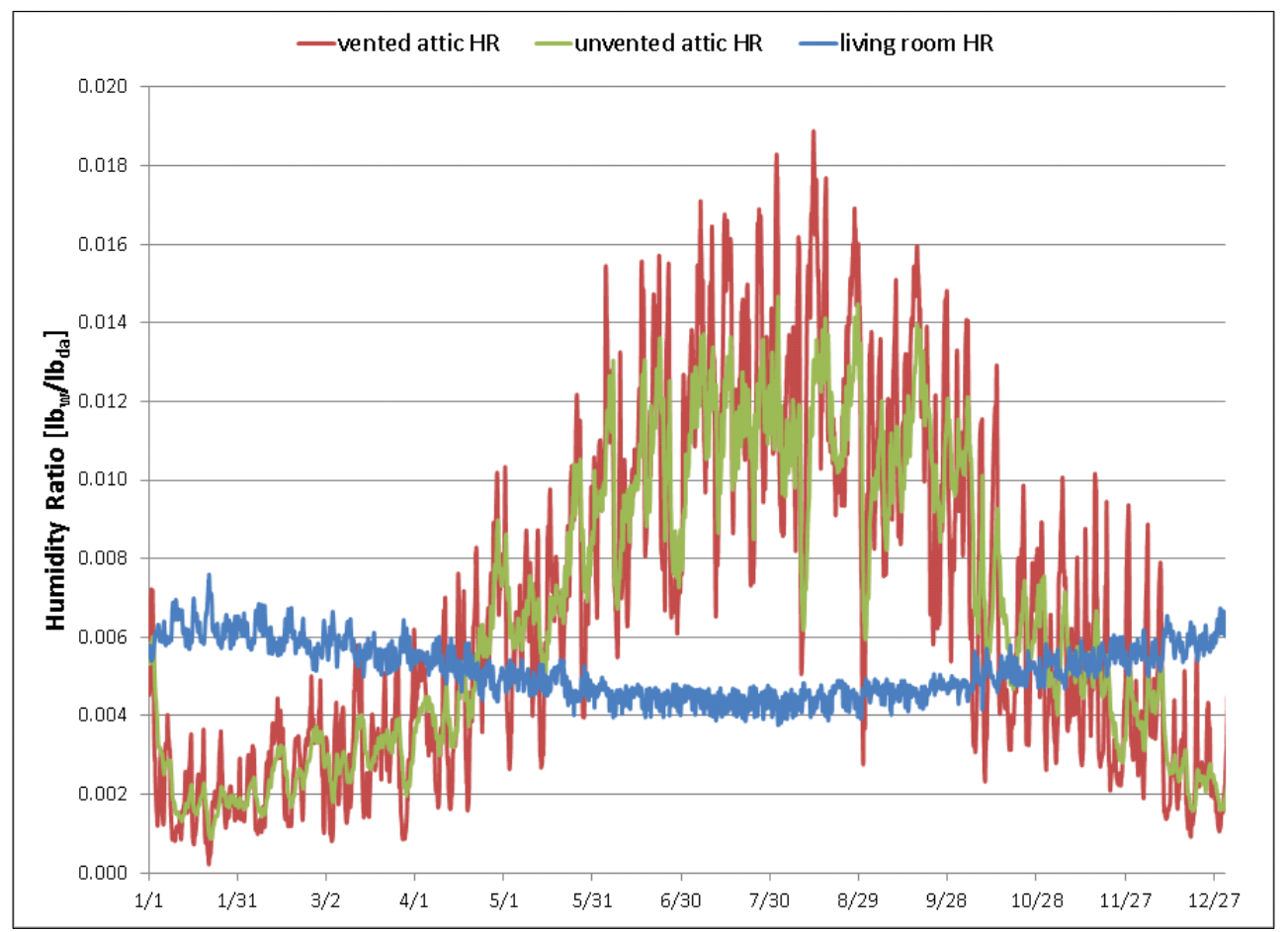

Figure 2. Average indoor and attic humidity ratio for vented and unvented attics 


\section{Experiment}

\subsection{Research Questions}

The research proposed here does not directly answer research questions concerning condensation potential and the integrity of unvented attic roof systems. Rather, it provides data to support the validation of an ORNL modeling effort that will attempt to answer those questions. The key research questions for this data collection effort were:

- Is it appropriate to assume that the unvented attic conditions are the same as the fully conditioned living space below?

- What interior boundary conditions should be used when modeling unvented roof assemblies; i.e., what are the appropriate attic space temperature and humidity ratio conditions?

- What variables have the greatest impact on the difference between the unvented attic and the conditioned space conditions?

\subsection{Methodology}

CARB's technical research efforts entailed:

- Developing the measurement plan to quantify the characteristics of each test site with respect to whole-house building tightness, attic leakage, living space leakage, and, if applicable, duct system leakage.

- Performing the house characterization testing and installing remote temperature and $\mathrm{RH}$ loggers in three selected test homes. Field monitoring was conducted from the November 2013 through August 2014.

- Collecting and scrubbing the data for model validation by ORNL. In addition, CARB analyzed the field data from the three test sites to determine if any trends could be identified.

\subsubsection{Sites}

Three unvented attics were investigated in this experiment and were all located in Connecticut (Figure 3), which is within DOE climate zone 5A. Basic characterizations of the three test sites are provided in Table 3 and Table 4. Each unvented attic was insulated with closed-cell spray polyurethane foam (ccSPF) at the roof deck, but two of the sites used alternative insulations to reach the final assembly R-values. The volume of the unvented attic in House 2 was the largest and it housed all the second-floor mechanicals, which included an energy recovery ventilator, air handler unit, and ductwork. Houses 1 and 3 had no mechanicals in the unvented attics. 


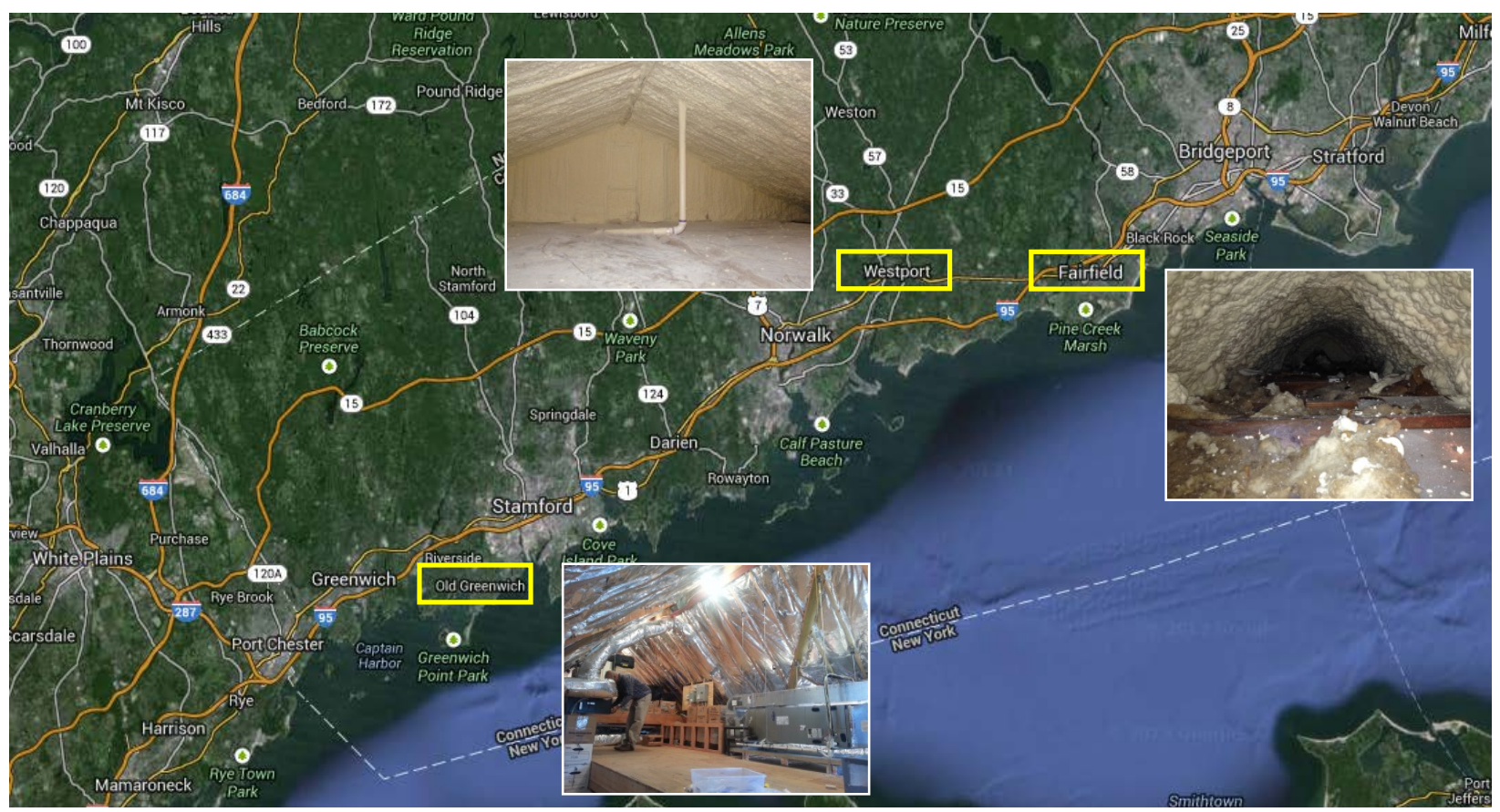

Figure 3. Locations of test sites

Table 3. Description of Each Test Site

\begin{tabular}{c|c|c}
\hline Site & House Type & Attic Type \\
\hline House 1 & $\begin{array}{c}\text { Energy-efficient home without ducts in } \\
\text { unvented attic }\end{array}$ & Full unfinished attic \\
House 2 & $\begin{array}{c}\text { Energy-efficient home with ducts in unvented } \\
\text { attic (supply side leakage) }\end{array}$ & Full unfinished attic \\
House 3 & $\begin{array}{c}\text { Existing cape style home with only an unvented } \\
\text { attic upgrade and no ducts in attic. }\end{array}$ & $\begin{array}{c}\text { Upper attic of a finished } \\
\text { Cape Cod attic* }\end{array}$ \\
\hline
\end{tabular}

* Refer to Figure 25.

Table 4. Summary of Unvented Attic Configurations

\begin{tabular}{|c|c|c|c|}
\hline & $\begin{array}{c}\text { House } 1 \\
\text { (Westport) }\end{array}$ & $\begin{array}{c}\text { House } 2 \\
\text { (Old Greenwich) }\end{array}$ & $\begin{array}{c}\text { House } 3 \\
\text { (Fairfield) }\end{array}$ \\
\hline $\begin{array}{c}\text { Surface Area }\left(\mathrm{ft}^{2}\right) \\
(\text { exposed/total) }\end{array}$ & $580 / 1,075$ & $1,239 / 2,285$ & $153 / 257$ \\
\hline Volume $\left(\mathrm{ft}^{3}\right)$ & 1,488 & 4,704 & 91 \\
\hline Insulation & 6.5-in. ccSPF (R-39) & $\begin{array}{l}\text { 4-in. ccSPF }(\mathrm{R}-27)+ \\
\text { 3-in. mineral wool batt } \\
(\mathrm{R}-12)+\text { foil-faced } \\
\text { fiber glass batt (R-13) }\end{array}$ & $\begin{array}{c}\text { 2-in. ccSPF }(\mathrm{R}-13)+ \\
6 \text {-in. open-cell spray } \\
\text { polyurethane foam } \\
(\text { ocSPF })(\mathrm{R}-22)\end{array}$ \\
\hline
\end{tabular}




\subsubsection{Sensor Placements}

Houses 1 and 2 had large spaces in the unvented attics $\left(1,488 \mathrm{ft}^{3}\right.$ and 4,704 $\mathrm{ft}^{3}$ in volume, respectively); thus, multiple sensors were used to determine if there were variations in the temperature and humidity conditions throughout those two attics. As sketched in Figure 4 and Figure 5, 15 sensors measuring temperature and RH were strategically placed in the unvented attics to determine the distribution of conditions in the attic. For the unvented attic in House 3, only one centrally located temperature/RH sensor was used because the unvented attic was only $91 \mathrm{ft}^{3}$ in volume.

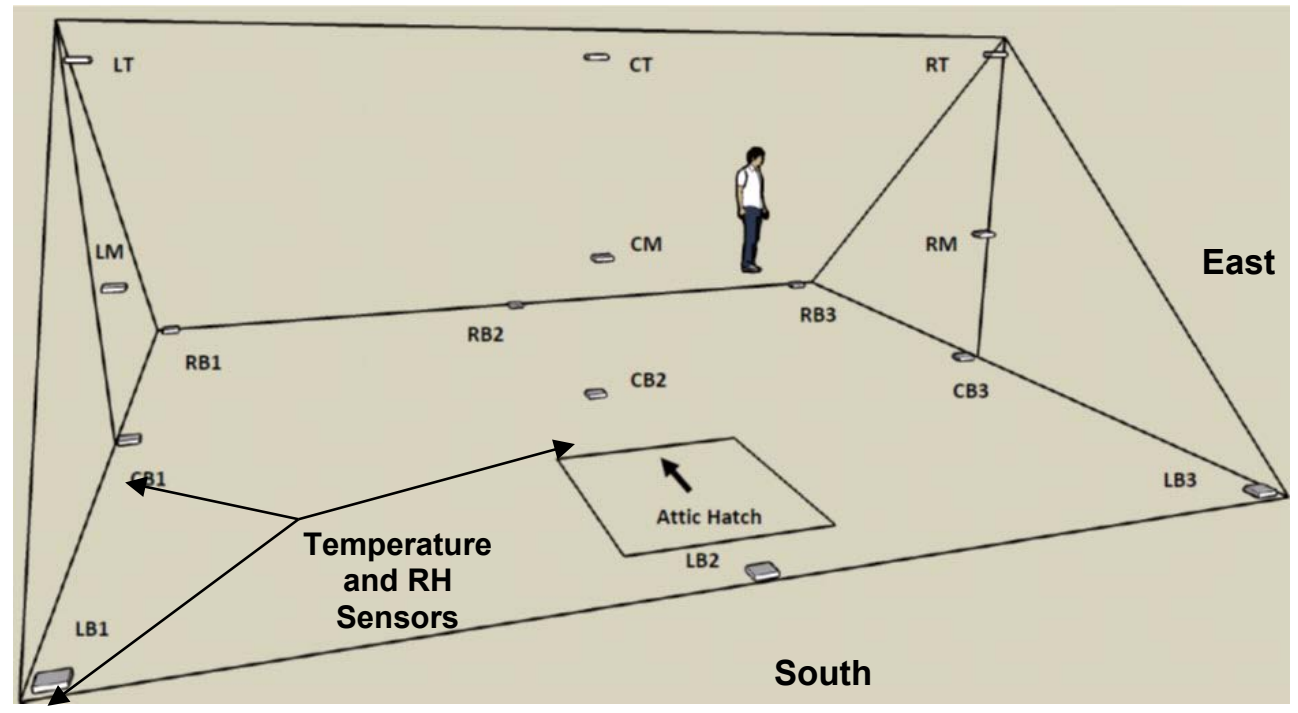

Figure 4. Sketch of Unvented Attic 1

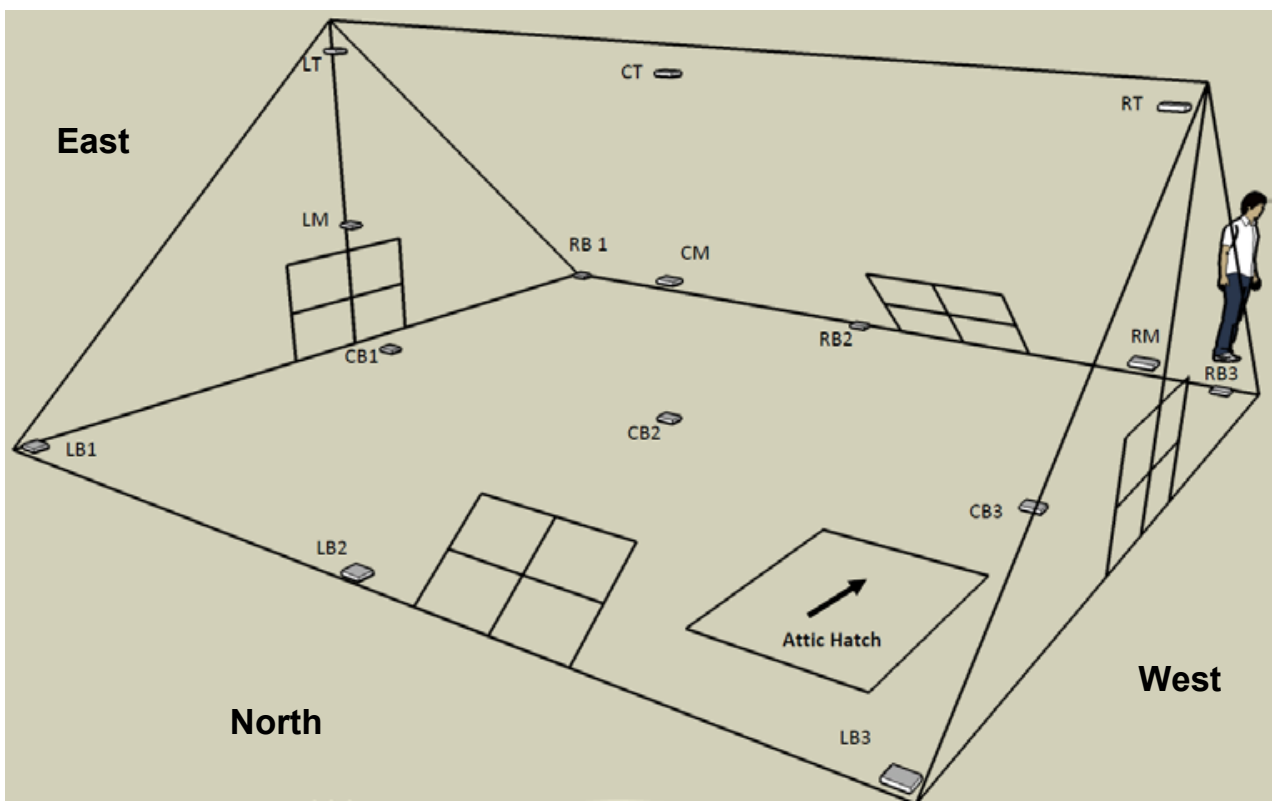

Figure 5. Sketch of Unvented Attic 2 
Analyzing the differential between the centrally placed temperature/RH sensor, $C M$, and other sensors in the unvented attic resulted in minimal differences. Looking at Table 5, average temperature and humidity ratio differences were all below $\pm 1^{\circ} \mathrm{F}$ and $\pm 0.00002 \mathrm{lb}_{\mathrm{w}} / \mathrm{lb}_{\mathrm{da}}( \pm 0.5 \%$ in terms of $\mathrm{RH}$ ), respectively, and the middle $80 \%$ range for temperature and humidity ratio differences in each unvented attic was less than $\pm 1^{\circ} \mathrm{F}$ and $\pm 0.00019 \mathrm{lb}_{\mathrm{w}} / \mathrm{lb}_{\mathrm{da}}( \pm 1.6 \%$ in terms of $\mathrm{RH})$, respectively. The temperature and humidity ratio distribution in Attic 1 is provided in Figure 6 and Figure 7, respectively. Other than some summertime variation in the humidity ratio at location $R B 3$ and $L B 1$ (as noted in Figure 4), which are likely due to summertime solar heat gain in the morning and afternoon, the $C M$ sensor is a good representation of the overall conditions in Unvented Attic 1. It was thereafter assumed that the $C M$ sensor is a suitable single point measurement of the overall unvented attic conditions when evaluating with respect to the living space for House 1.

Table 5. Average Temperature and Humidity Ratio Difference Between Centrally Placed Sensor and Other Sensors Placed All Around the Unvented Attic Space Over Winter and Spring

\begin{tabular}{c|c|c|c|c}
\hline \multirow{2}{*}{ Attic } & \multicolumn{2}{|c|}{$\mathbf{8 0 \%}$ Range (Min-Max) } & \multicolumn{2}{c}{ Average } \\
\cline { 2 - 5 } & $\begin{array}{c}\text { Temperature } \\
\text { Difference } \\
\left({ }^{\circ} \mathbf{F}\right)\end{array}$ & $\begin{array}{c}\text { Humidity Ratio } \\
\text { Difference } \\
\text { (lbw/lbda) }\end{array}$ & $\begin{array}{c}\text { Temperature } \\
\text { Difference } \\
\left({ }^{\circ} \mathbf{F}\right)\end{array}$ & $\begin{array}{c}\text { Humidity Ratio } \\
\text { Difference } \\
\text { (lbw/lbda) }\end{array}$ \\
\hline $\mathbf{1}$ & -0.9 to 0.7 & -0.00011 to 0.00019 & -0.12 & 0.00002 \\
$\mathbf{2}$ & -1.7 to 0.2 & -0.00039 to 0.00011 & -0.60 & -0.00009 \\
\hline
\end{tabular}

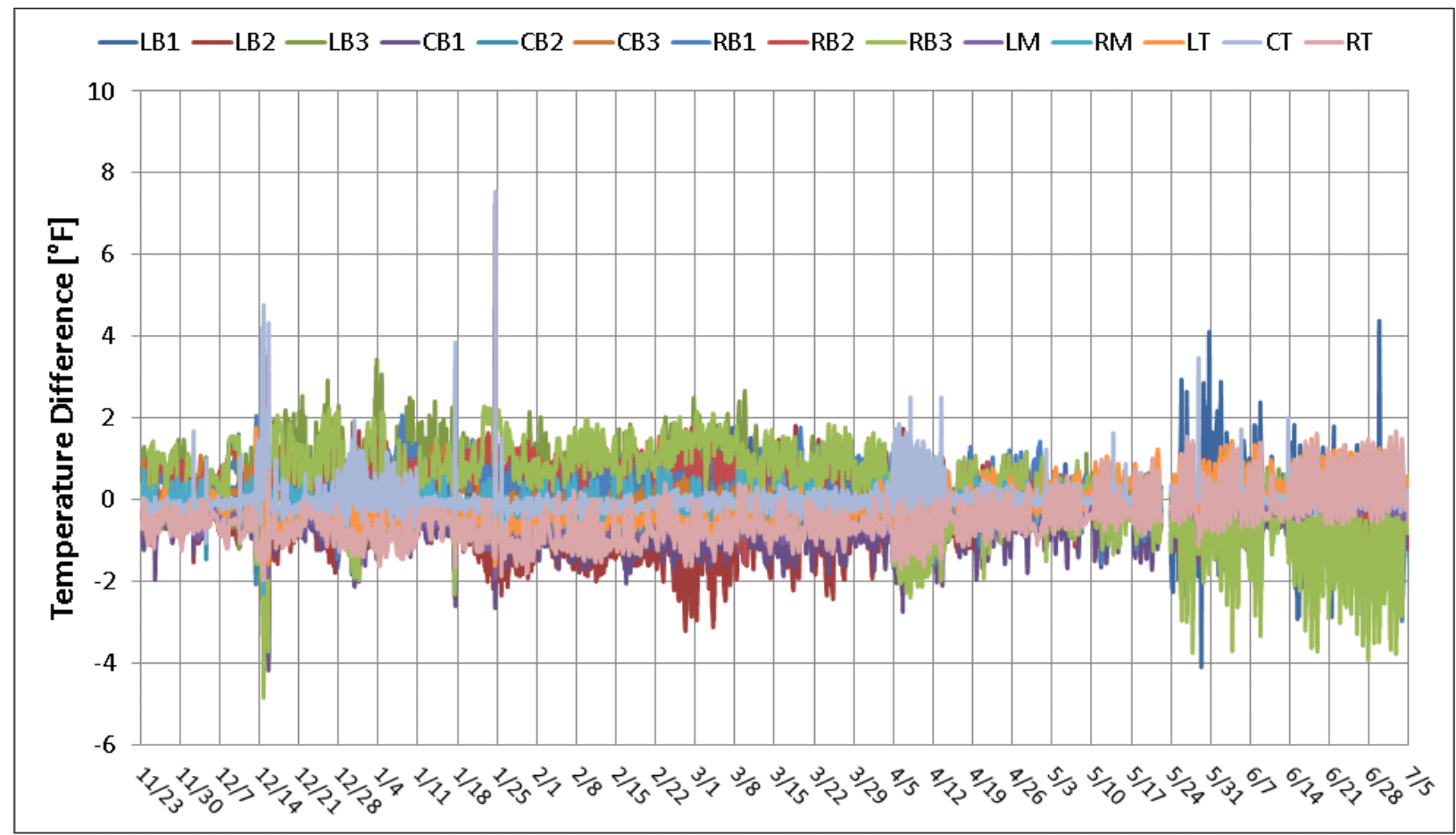

Figure 6. Temperature differences between sensor at $\mathrm{CM}$ and sensors at other positions in Unvented Attic 1 


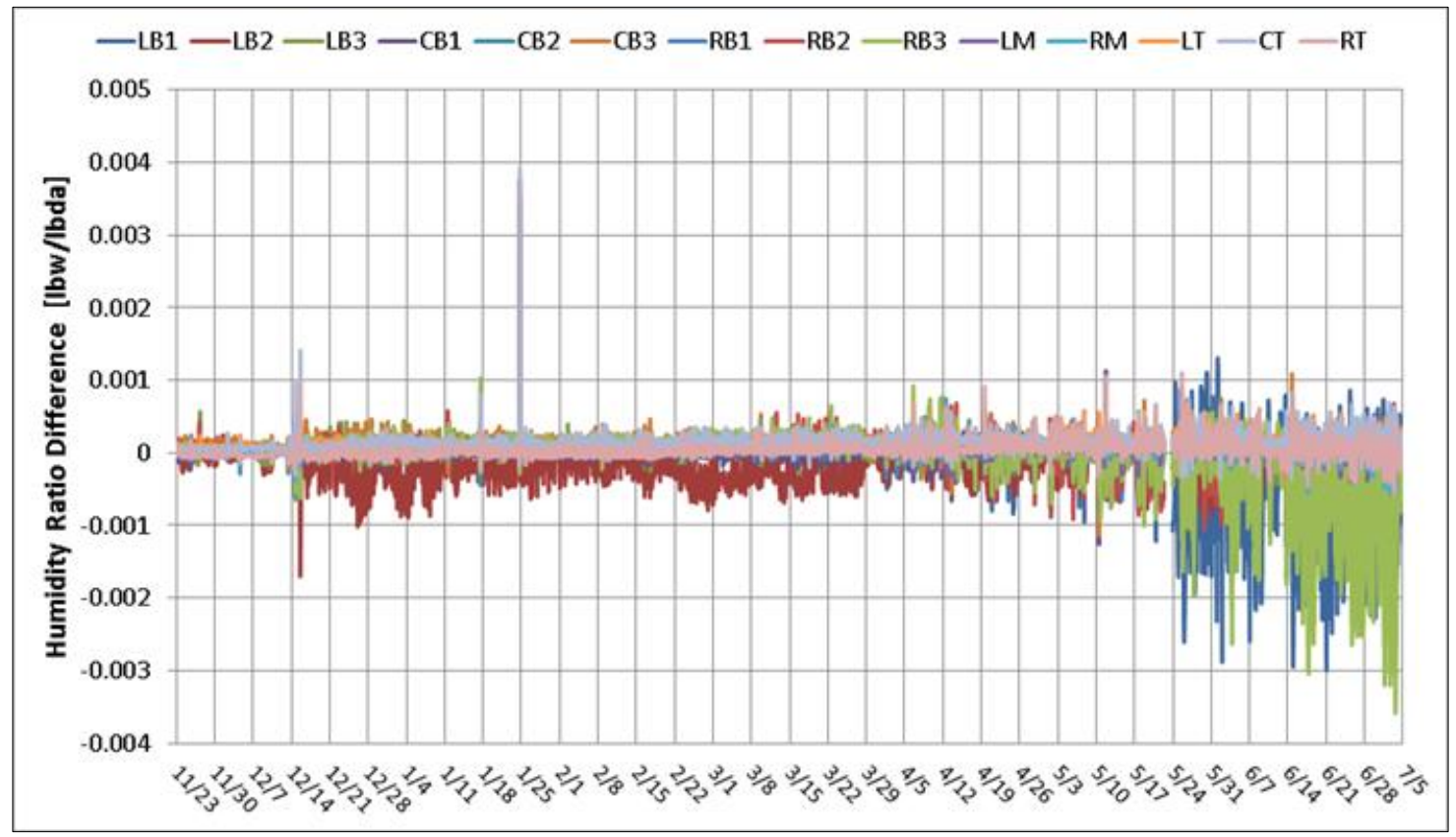

Figure 7. Humidity ratio differences between sensor at $\mathrm{CM}$ and sensors at other positions in Unvented Attic 1

Unvented Attic 2 had similar trends in the temperature measurements of all attic sensors (Figure 8 ), with most measurements within a range of $\pm 4^{\circ} \mathrm{F}$. Unvented Attic 2 shows is an anomaly with the humidity measurements along the attic ridge versus the central measurement point during the summer months (Figure 9), even though the ridge temperature measurements are within a range of $-0.5^{\circ} \mathrm{F}$ to $1.5^{\circ} \mathrm{F}$ of the $C M$ temperature measurement. As the $L T$ humidity ratio measurement seems to lag the outdoor conditions (Figure 10), this anomaly may be a result of air leakage at the ridge beam that is impacting the upper measurement sensors. For the purposes of the analysis of the unvented attic with respect to the living space for House 2, the $C M$ sensor will still be used as a representative measurement of the overall attic conditions. 


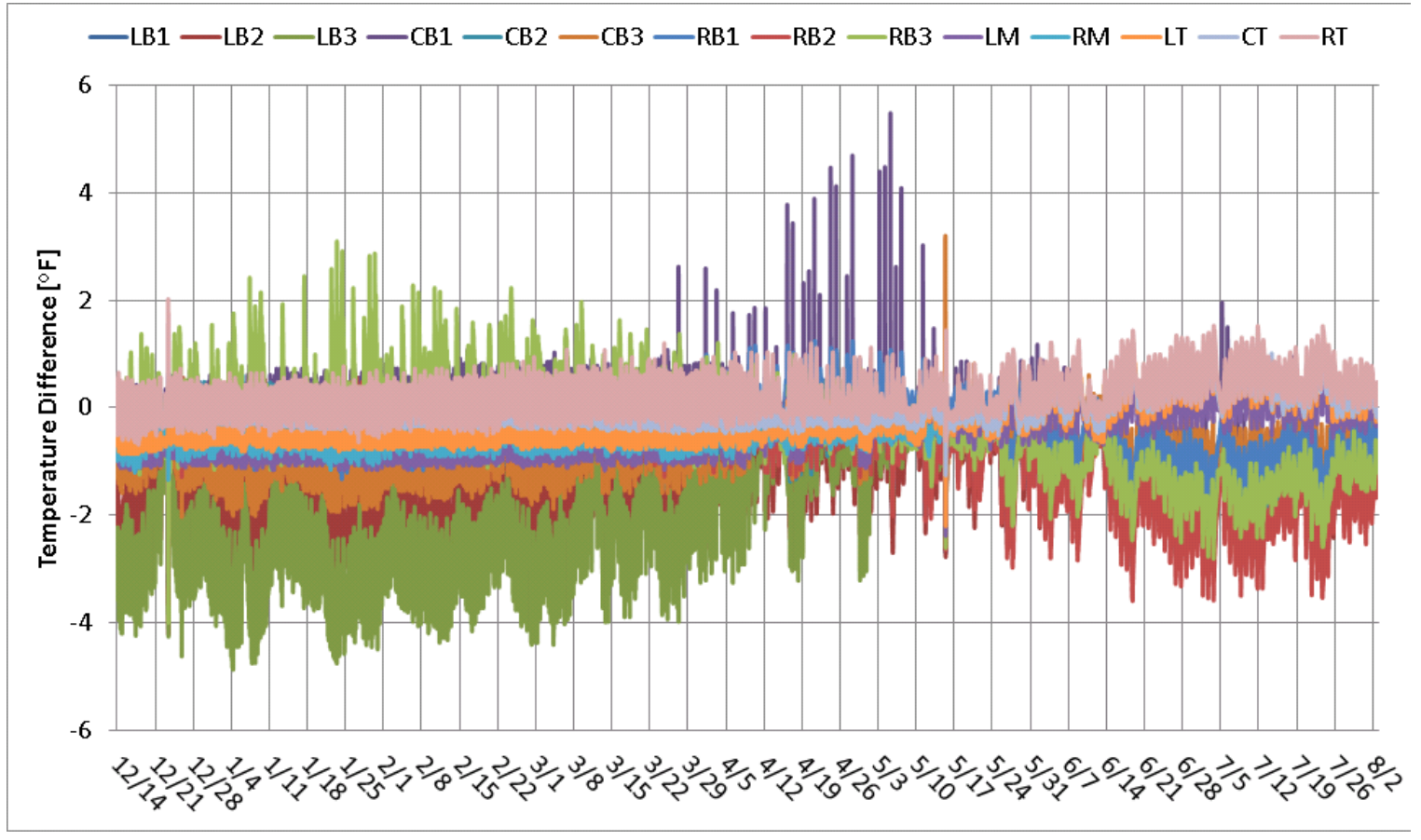

Figure 8. Temperature differences between sensor at $\mathrm{CM}$ and sensors at other positions in Unvented Attic 2

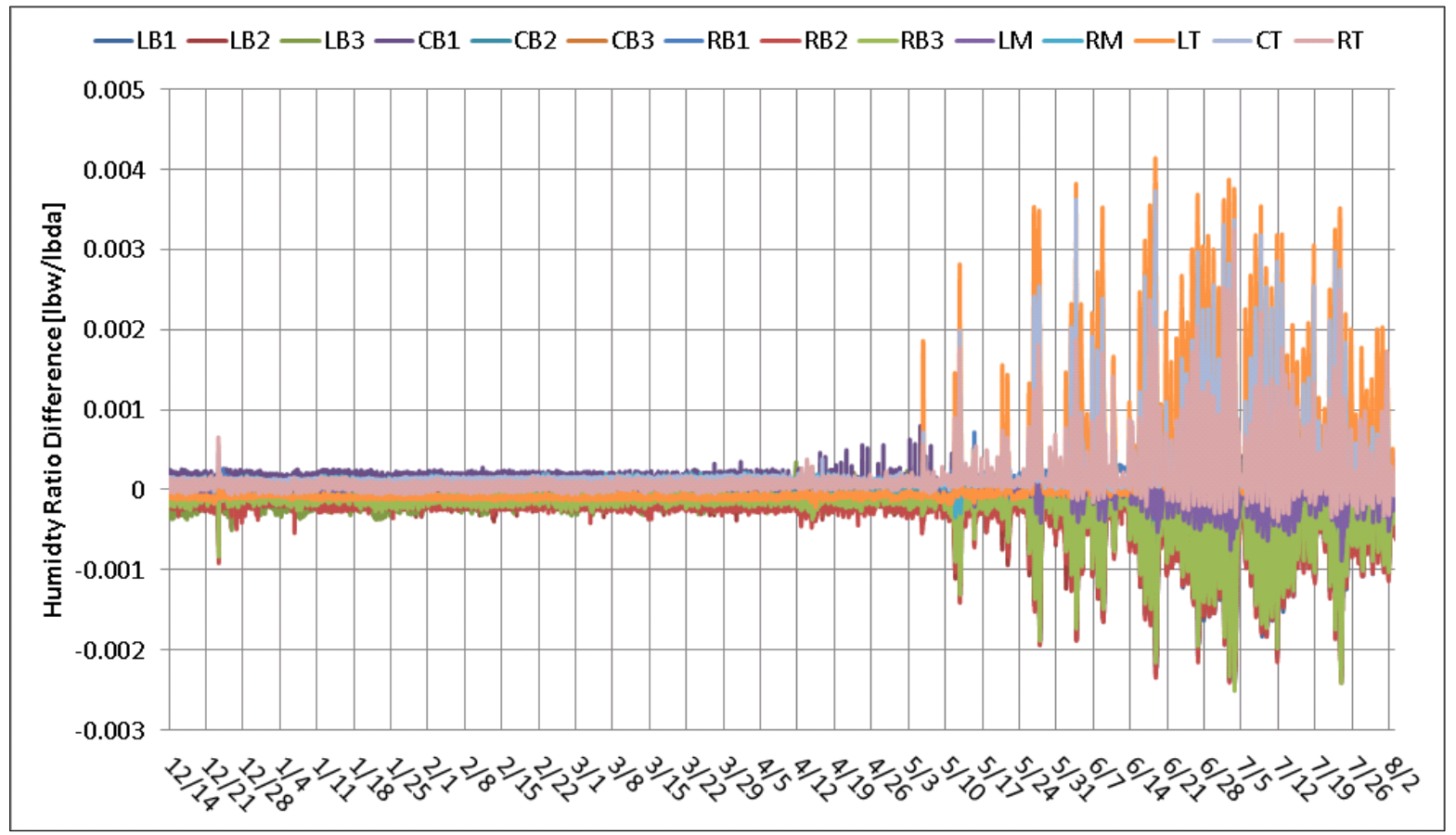

Figure 9. Humidity ratio differences between sensor at $\mathrm{CM}$ and sensors at other positions in Unvented Attic 2 


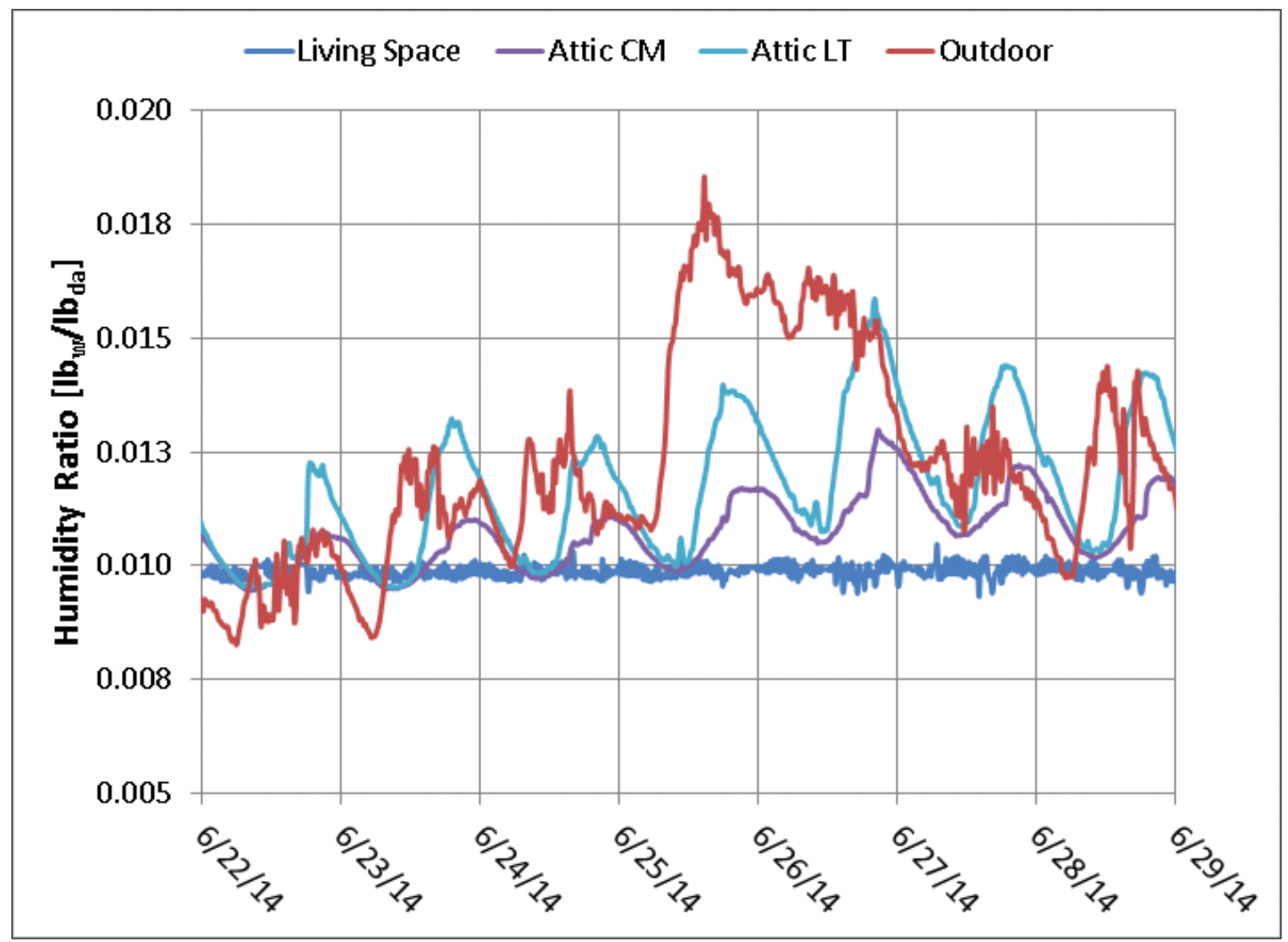

Figure 10. Humidity ratio at the CM and LT sensors, in the living space, and outdoors at House 2 for a typical summer week

\subsubsection{Characterization of Test Sites-Building Leakage Testing}

Depressurization tests were performed to determine how connected the three test attics were to the conditioned spaces. This connectivity was determined by zonal pressure diagnostics. The building envelope air leakage area was determined using a multipoint depressurization test at 10 , 20, 30, 40, 50, and $60 \mathrm{~Pa}$ to enable a linear regression analysis following ASTM E779 test procedures. The specific test configurations that were used to quantify the connectivity of the unvented attics to living spaces are illustrated in Figure 11 through Figure 14.

Initially, standalone depressurization tests were performed with the houses in the following configurations:

- Figure 11: Attic hatch open

- Figure 12: Attic hatch closed (natural state)

- Figure 13: Attic hatch closed (sealed with tape). 
The pressure differential between the attic and the living space was recorded at each test pressure.

Afterward, an additional test fan was located in the attic hatch to perform guarded pressure testing (Figure 14). At each pressure, the attic test fan was used to bring the unvented attic pressure to the same as the living space.

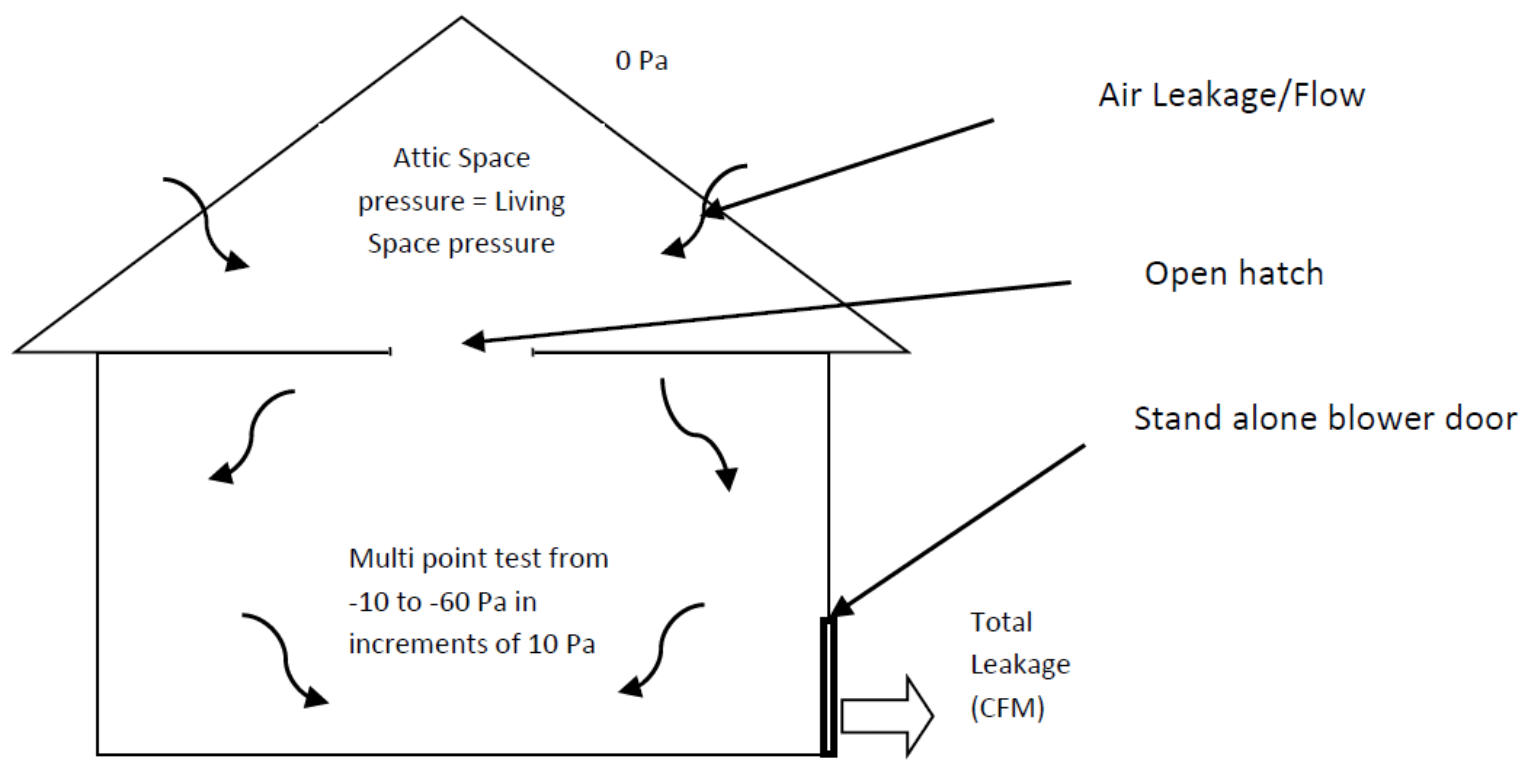

Figure 11. Depressurization test with unvented attic hatch open

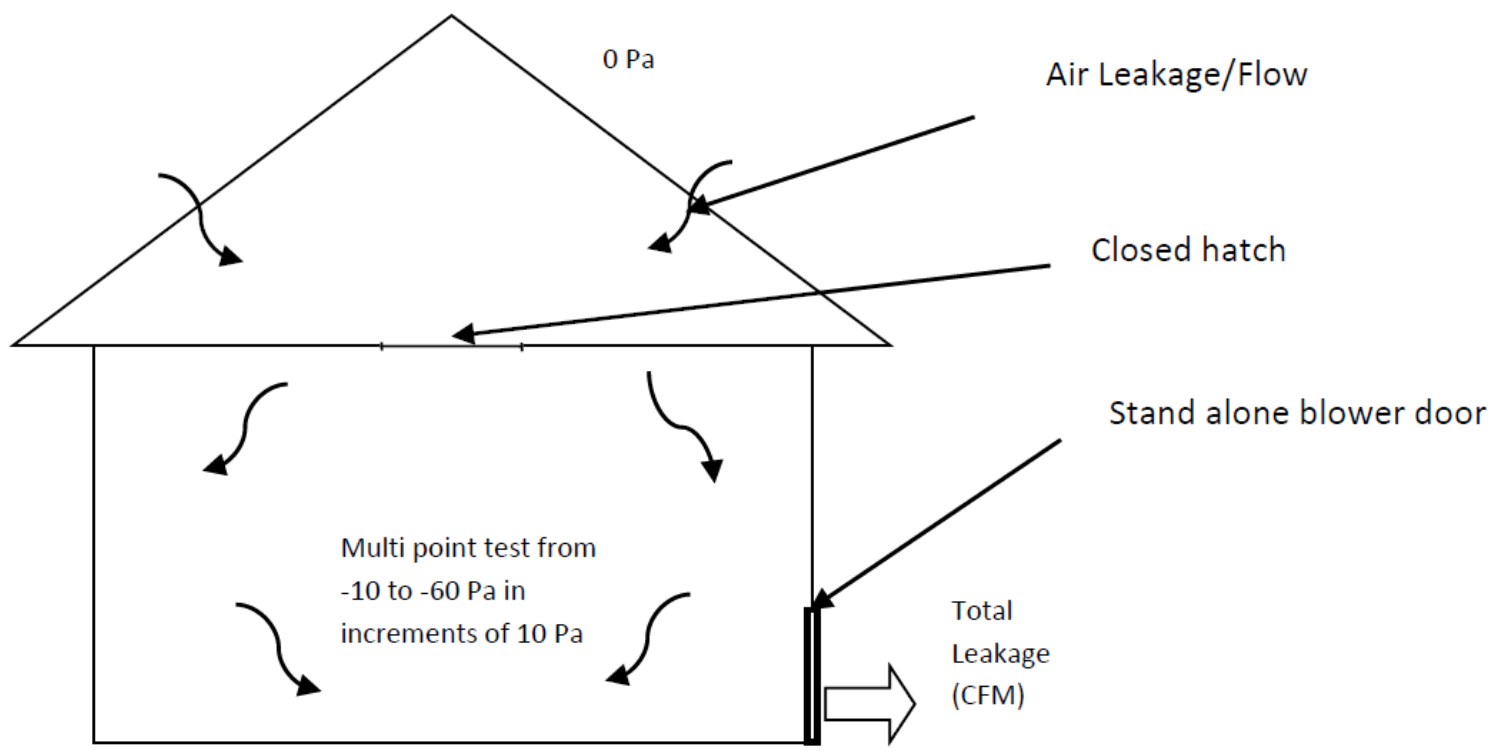

Figure 12. Depressurization test with unvented attic hatch closed 


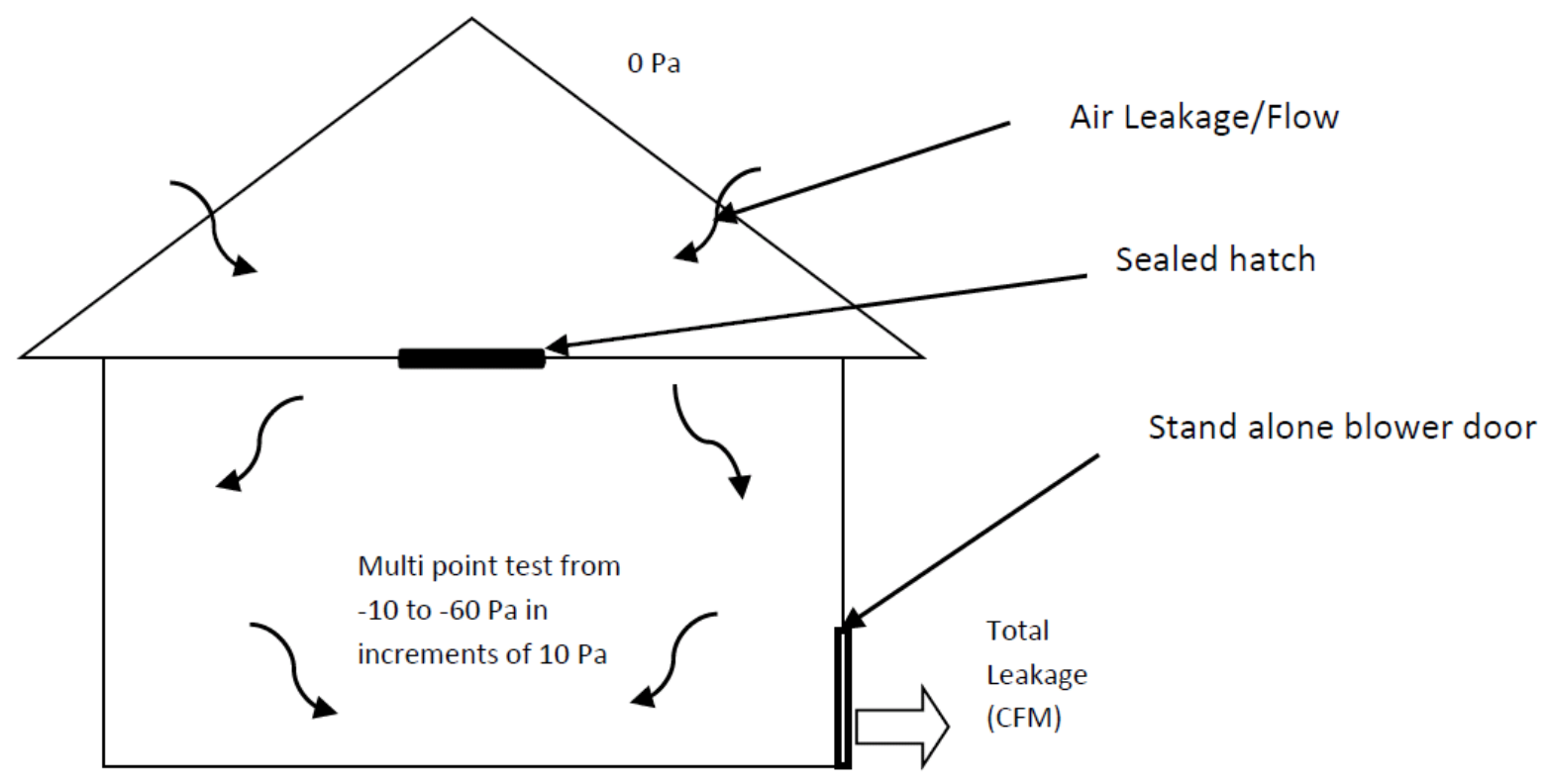

Figure 13. Depressurization test with unvented attic hatch carefully sealed

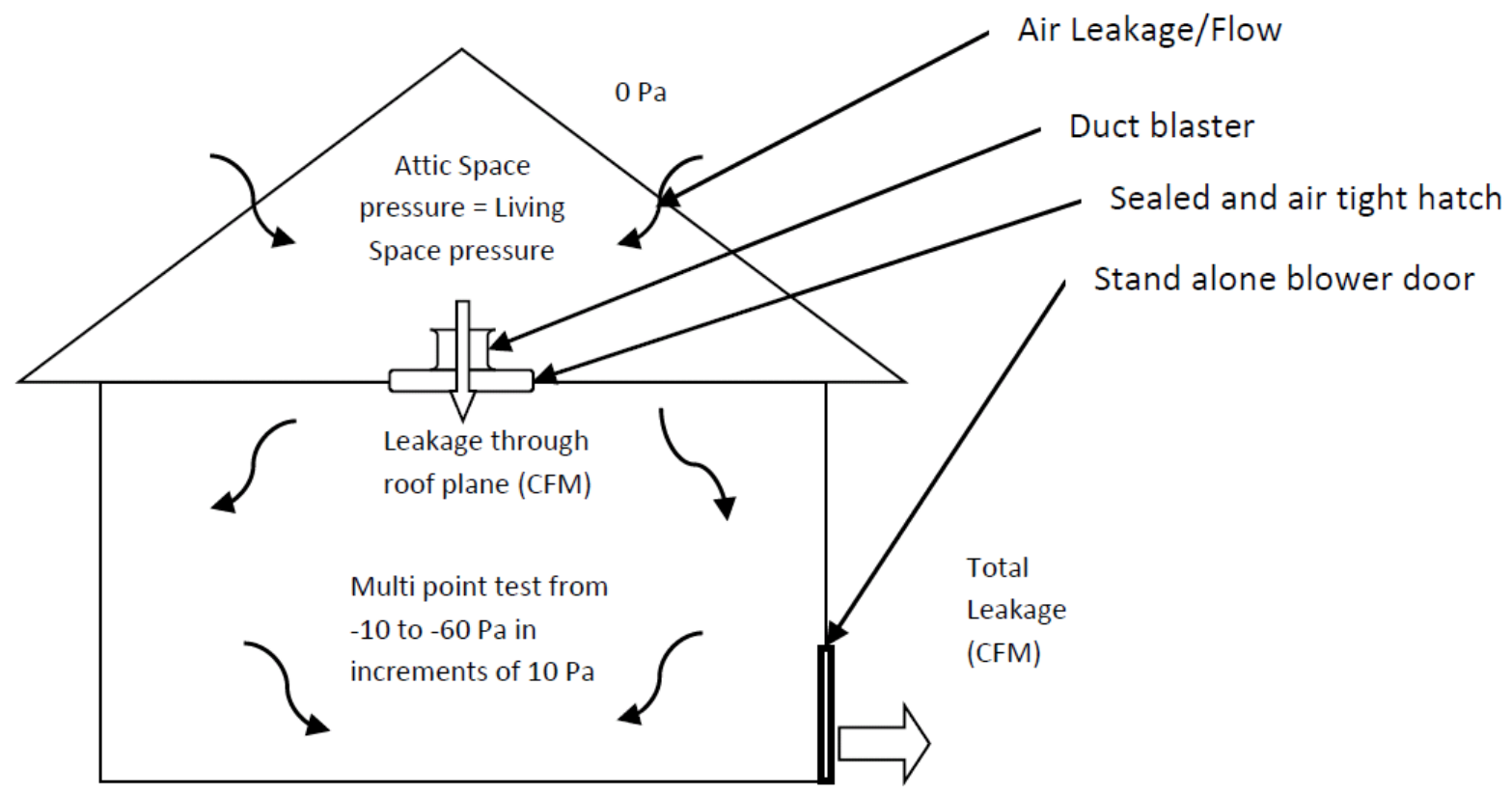

Figure 14. Depressurization test of house and attic. The attic depressurization flow rate minus the difference between blower door cfm50 with the attic hatch open and closed is the leakage of just the unvented attic.

The attic-to-living space "coupling factor" was also measured. This was defined as the ratio of the attic-to-outdoor differential pressure to the home-to-outdoor differential pressure at -50 
Pascal. A coupling factor of zero indicates no air transport between the attic and living space, while a value of one means that these two spaces are completely connected.

\subsubsection{Characterization of Test Sites-Duct Leakage Testing}

A duct pressurization test was used to measure total duct leakage, as well as supply and return duct leakage, in House 2. The other two sites did not have ductwork. It is important to know whether leakage is on the supply or return side to accurately analyze the impact of the duct leakage on the unvented attic's interaction with the living space below.

\subsubsection{Characterization of Test Sites-Solar Irradiance}

Because all three sites are within 20 miles of each other, solar irradiance was monitored at House 1 only. Though not a part of the original test plan, this field monitoring was included for the period of March 2014 to July 2014 to compare measured values to the assumptions in a BEopt simulation and to assist the modeling validation work that ORNL will perform.

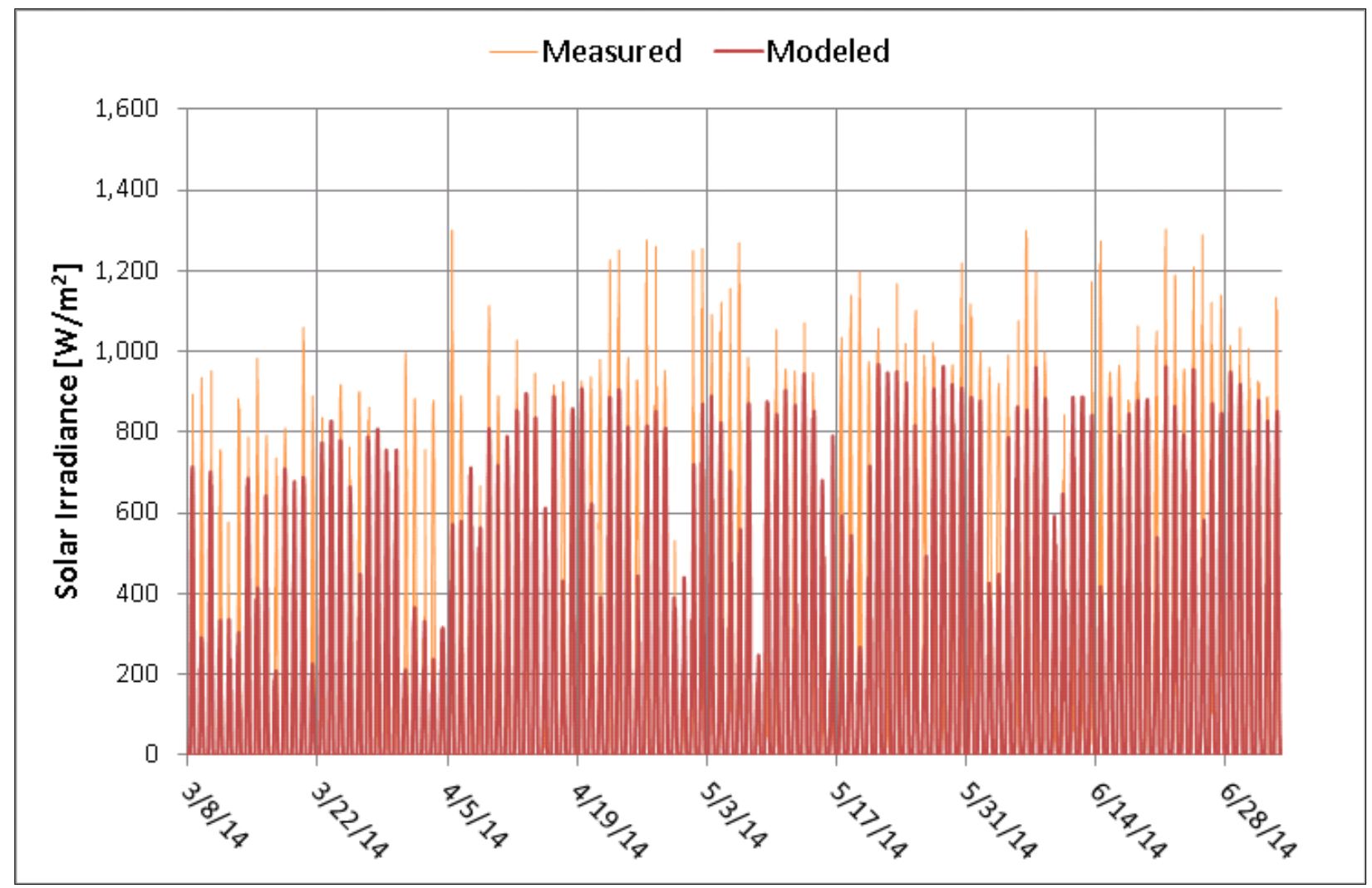

Figure 15. Global horizontal irradiance

When taking a closer look at the solar data (Figure 16), the attic temperature profile slightly lags the outdoor temperature profile, which slightly lags the solar irradiance profile, as anticipated. 


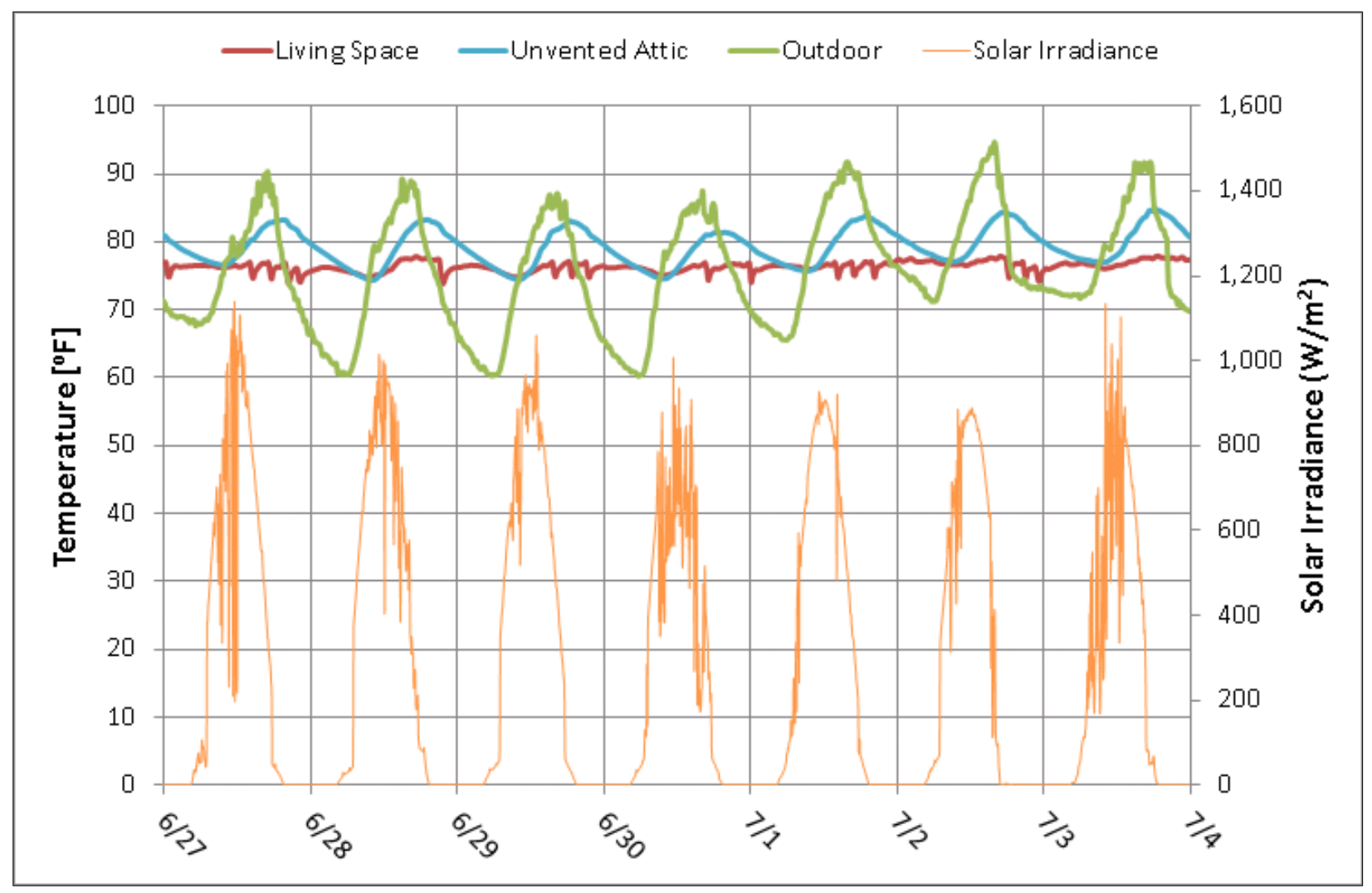

Figure 16. Summer impact of solar irradiance on Unvented Attic 1 


\section{Results}

\subsection{Performance Testing}

The following are results of the house characterization performance testing for each test home. For all three homes, the attic-to-living space "coupling factor" was in the $0.84-0.89$ range, meaning that the unvented attics were well connected to the living space.

\subsubsection{House 1}

In Table 6, the attic depressurization airflow, $163 \mathrm{cfm}$ at $-50 \mathrm{~Pa}$, is the leakage between the attic and the outside. While an unvented attic, nearly a quarter of the whole-house leakage is still through this building component. The total building leakage of $658 \mathrm{cfm}_{50}$ translates to an $\mathrm{ACH}_{50}$ of $\sim 1.9$ for the home.

Table 6. Whole-Building Depressurization Test Results at House 1

\begin{tabular}{c|c|c|c|c|c|c|c|}
\hline $\begin{array}{c}\text { House Depressurization } \\
(-1.6 \text { Pa Baseline) }\end{array}$ & CFM10 & CFM20 & CFM30 & CFM40 & CFM50 & CFM60 \\
\hline \multicolumn{7}{c|}{ House Depressurization Airflow (CFM) } \\
\hline $\begin{array}{c}\text { Open Attic Hatch } \\
\text { Closed Attic Hatch }\end{array}$ & 203 & 352 & 459 & 563 & 659 & 736 \\
\hline Sealed Attic Hatch & 219 & 337 & 456 & 553 & 628 & 738 \\
\hline \multicolumn{7}{c}{ Pressure Differential of Attic With Respect to House (Pa) } \\
\hline $\begin{array}{c}\text { Open Attic Hatch } \\
\text { Closed Attic Hatch }\end{array}$ & 0 & 0 & 0 & 0 & 0 & 0 \\
\hline $\begin{array}{c}\text { Sealed Attic Hatch } \\
\text { Attic Depressurization }\end{array}$ & 0.5 & 1.3 & 2.1 & 2.9 & 3.6 & 4.9 \\
$\begin{array}{c}\text { Airflow for Neutral Pressure } \\
\text { to House (CFM) }\end{array}$ & 41 & 82 & 120 & 135 & 163 & 187 \\
$\begin{array}{c}\text { House Depressurization } \\
\text { Airflow (CFM) }\end{array}$ & 224 & 347 & 477 & 558 & 658 & 753 \\
\hline
\end{tabular}

The various test scenarios indicate that all the leakage to the outside (both from outside to the attic and from the house below the ceiling) goes through the blower door and that the total leakage of $658 \mathrm{cfm}$ at $-50 \mathrm{~Pa}$ is nearly identical to the first test with the attic access open (659 cfm at $-50 \mathrm{~Pa}$ ), which results in no pressure difference between the house and the attic. This is a good, quick check that testing results make sense. Therefore, the leakage from outside into the house below the attic at $50 \mathrm{~Pa}$ is $658-163=495 \mathrm{cfm}$.

\subsubsection{House 2}

The results of the whole-building depressurization testing at House 2 were fairly similar to House 1. Building leakage at $-50 \mathrm{~Pa}$ was $724 \mathrm{cfm}_{50}$, which translates to an $\mathrm{ACH}_{50}$ of $\sim 1.2$ for the home. Of that total building leakage, $161 \mathrm{cfm}_{50}$ was through the attic to outdoors. 
Table 7. Whole-Building Depressurization Test Results at House 2

\begin{tabular}{c|c|c|c|c|c|c|c}
\hline $\begin{array}{c}\text { House Depressurization } \\
\text { (-1.5 Pa Baseline) }\end{array}$ & CFM10 & CFM20 & CFM30 & CFM40 & CFM50 & CFM60 \\
\hline \multicolumn{7}{c}{ House Depressurization Airflow (CFM) } \\
\hline $\begin{array}{c}\text { Open Attic Hatch } \\
\text { Olosed/Sealed Attic Hatch }\end{array}$ & 180 & 344 & 497 & 605 & 724 & 787 \\
\hline Pressure Differential of Attic With Respect to House (Pa) \\
\hline $\begin{array}{c}\text { Open Attic Hatch } \\
\text { Clo }\end{array}$ & 0 & 0 & 0 & 0 & 0 & 0 \\
\hline $\begin{array}{c}\text { Closed/Sealed Attic Hatch } \\
\text { Attic Depressurization } \\
\text { Airflow for Neutral Pressure } \\
\text { to House (CFM) }\end{array}$ & 1.3 & 2.6 & 3.8 & 4.8 & 5.8 & 7.1 \\
\hline $\begin{array}{c}\text { House Depressurization } \\
\text { Airflow (CFM) }\end{array}$ & 194 & 342 & 465 & 576 & 676 & 779 \\
\hline
\end{tabular}

This test site was the only one with ductwork in the unvented attic. Duct leakage test results (Table 8) suggest that the overall duct system is fairly well air sealed with a small percentage of leakage on the supply side. While the total duct leakage was measured to be $92 \mathrm{cfm}_{25}$, the leakage to the attic was only $45 \mathrm{cfm}_{25}$. The air handler flow ranged from $450-600$ depending on operational mode of the unit.

Table 8. Duct Leakage Test Results at House 2

\begin{tabular}{|c|c|}
\hline Total Duct Leakage & cfm \\
\hline Total & 92 \\
Supply & 89 \\
Return & 3 \\
\hline Leakage to Attic & cfm \\
\hline Total & 45 \\
\hline Supply & 44 \\
\hline Return & 1 \\
\hline
\end{tabular}

\subsubsection{House 3}

House 3 had air sealing improvements to the attic only. The exterior walls had not been air sealed, so the overall building tightness of this home was the lowest, even though it was the smallest test home. Building leakage at $-50 \mathrm{~Pa}$ was $1,365 \mathrm{cfm}_{50}$, which translates to an $\mathrm{ACH}_{50}$ of $\sim 8.3$ for the home. Of that total building leakage, $14 \mathrm{cfm}_{50}$ was through the attic to outdoors. 
Table 9. Whole-Building Depressurization Test Results at House 3

\begin{tabular}{|c|c|c|c|c|c|c|}
\hline $\begin{array}{l}\text { House Depressurization } \\
\text { (-1.6 Pa Baseline) }\end{array}$ & CFM10 & CFM20 & CFM30 & CFM40 & CFM50 & CFM60 \\
\hline \multicolumn{7}{|c|}{ House Depressurization Airflow (CFM) } \\
\hline Open Attic Hatch & 427 & 725 & 993 & 1,165 & 1,351 & 1,535 \\
\hline Closed/Sealed Attic Hatch & 432 & 730 & 989 & 1,173 & 1,356 & 1,523 \\
\hline \multicolumn{7}{|c|}{ Pressure Differential of Attic With Respect to House (Pa) } \\
\hline Open Attic Hatch & 0 & 0 & 0 & 0 & 0 & 0 \\
\hline $\begin{array}{l}\text { Closed/Sealed Attic Hatch } \\
\text { Attic Depressurization }\end{array}$ & 0.6 & 2.2 & 4.2 & 6 & 8 & 10 \\
\hline $\begin{array}{c}\text { Airflow for Neutral Pressure } \\
\text { to House (CFM) }\end{array}$ & - & - & 12 & 14 & 18 & 20 \\
\hline $\begin{array}{c}\text { House Depressurization } \\
\text { Airflow (CFM) }\end{array}$ & 465 & 755 & 986 & 1,200 & 1,365 & 1,530 \\
\hline
\end{tabular}

\subsection{Field Monitoring}

The results of the temperature and RH monitoring for each test home follow.

\subsubsection{House 1}

Figure 17 shows conditions at House 1 from mid-December 2013 through the end of June 2014 (a data collection issue resulted in the loss of July data for outdoor conditions, but peak design conditions occurred in the June data, so the data should be representative of the summer months). The living space temperature fluctuates a little during December as heating was being supplied by an inverter-driven air-source heat pump. Starting in January, the hydronic baseboard system was used for the space heating. The heating set point was $70^{\circ} \mathrm{F}$. In the summer months, the airsource heat pump was once again used to now provide space cooling at a set point of $75^{\circ} \mathrm{F}$. Looking at this temperature differential as a function of outdoor air temperature (Figure 18), the general trend is for the unvented attic to be slightly cooler than the living space in winter (down to $\sim 7.5^{\circ} \mathrm{F}$ ), roughly the same in the spring, and slightly warmer in the summer (up to $\sim 7.5^{\circ} \mathrm{F}$ ).

Figure 19 shows the humidity ratio conditions at House 1 . Humidity ratio, rather than RH, is presented because it is the total amount of water vapor present in a given volume and does not take temperature into consideration. Except for the beginning of summer, the humidity ratio of the unvented attic was fairly similar to the living space conditions (Figure 20). 


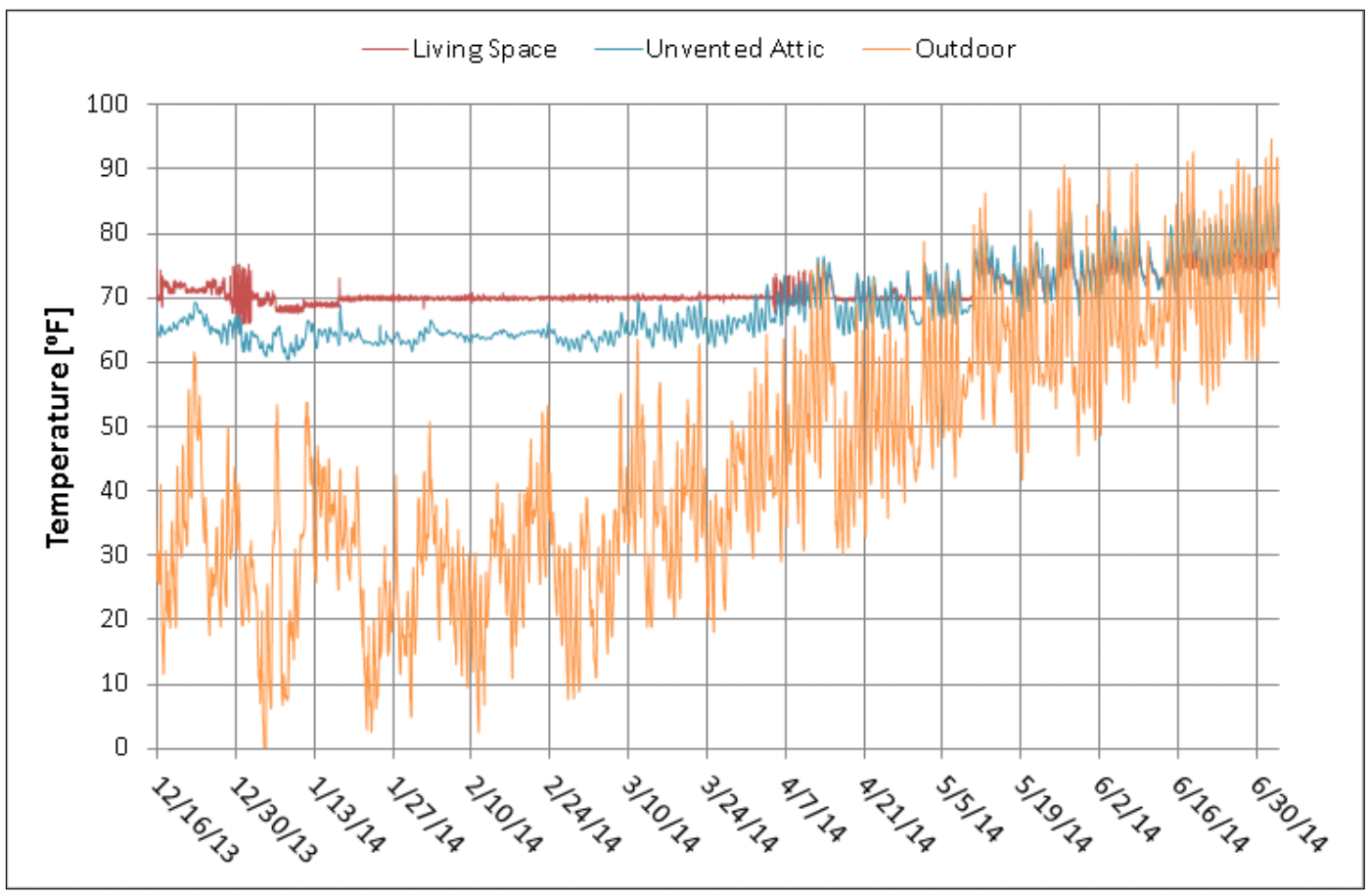

Figure 17. Temperature conditions at House 1

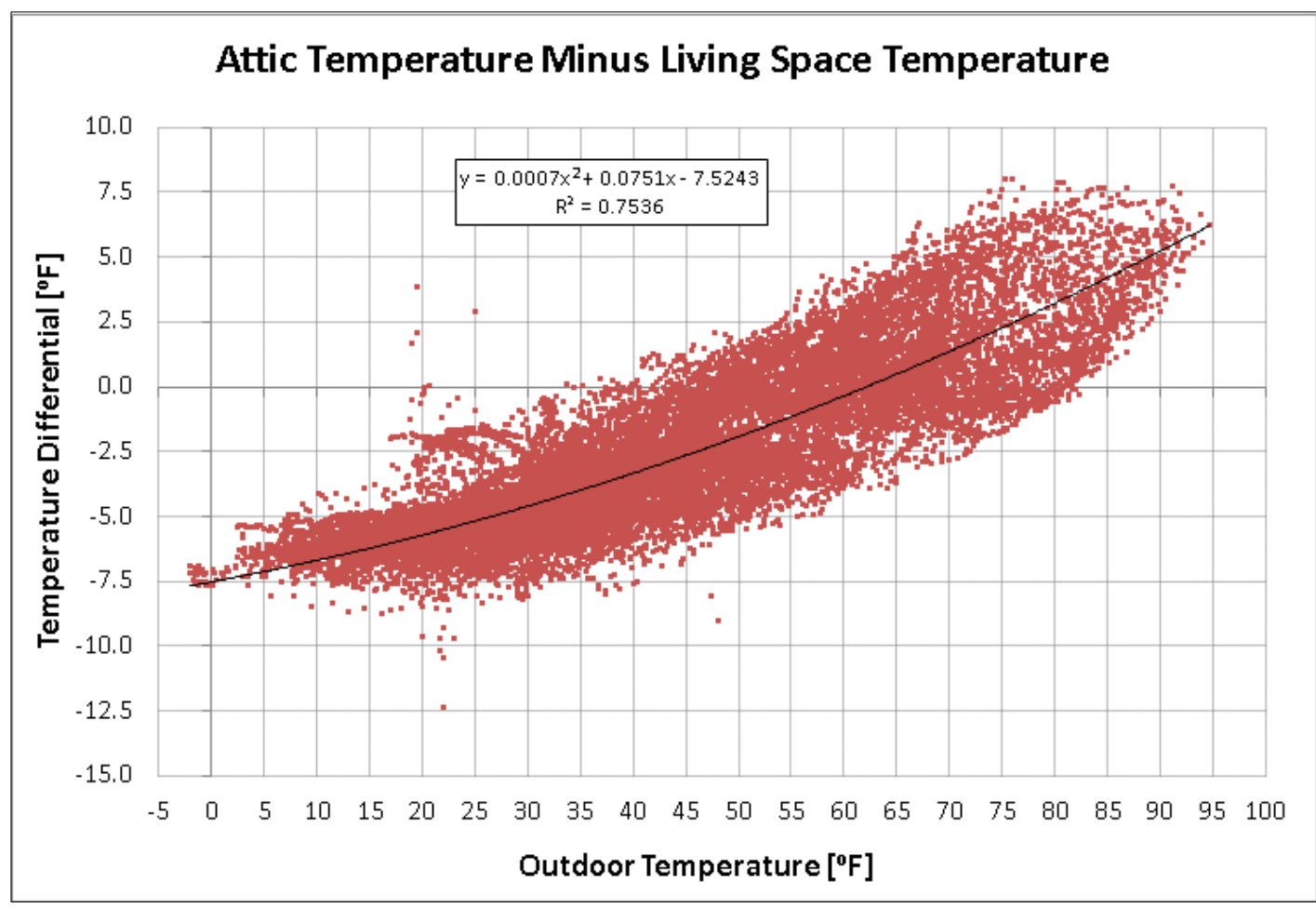

Figure 18. House 1 temperature differential with respect to outdoor temperature 


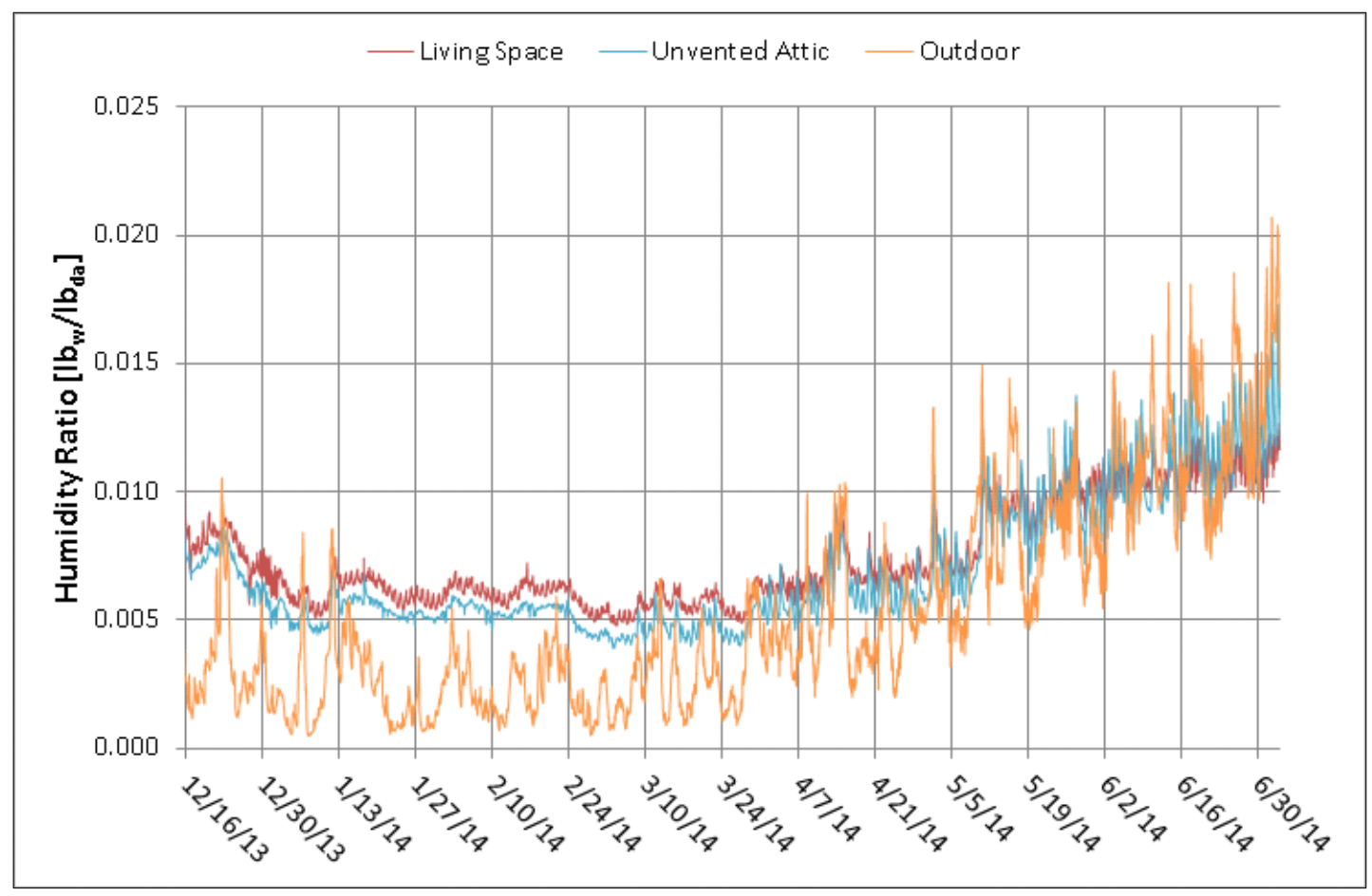

Figure 19. Humidity conditions at House 1

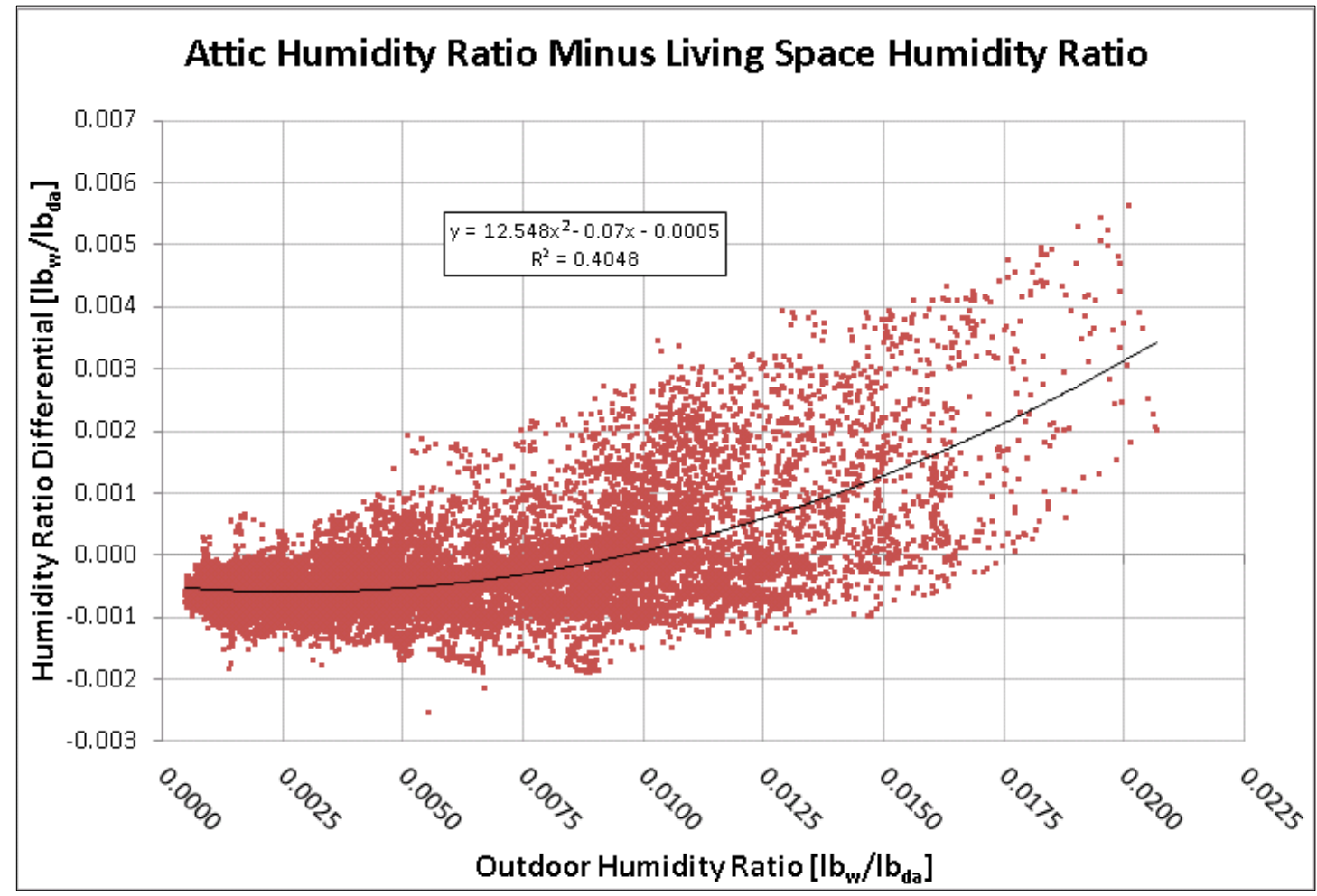

Figure 20. House 1 humidity ratio differential with respect to outdoor humidity ratio 


\subsubsection{House 2}

Even more so than House 1, the attic conditions in House 2 track fairly closely to living space conditions (Figure 21). The small amount of space conditioning that is leaking from the distribution system to the attic likely caused this small range in temperature differential (Figure 22). The home operated at a set point of $70^{\circ} \mathrm{F}$ for most of the winter and a set point of $72^{\circ} \mathrm{F}$ for much of the summer.

Figure 23 shows the humidity ratio conditions at House 2. Again, except for the beginning of summer, the humidity ratio of the unvented attic was fairly similar to the living space conditions (Figure 24).

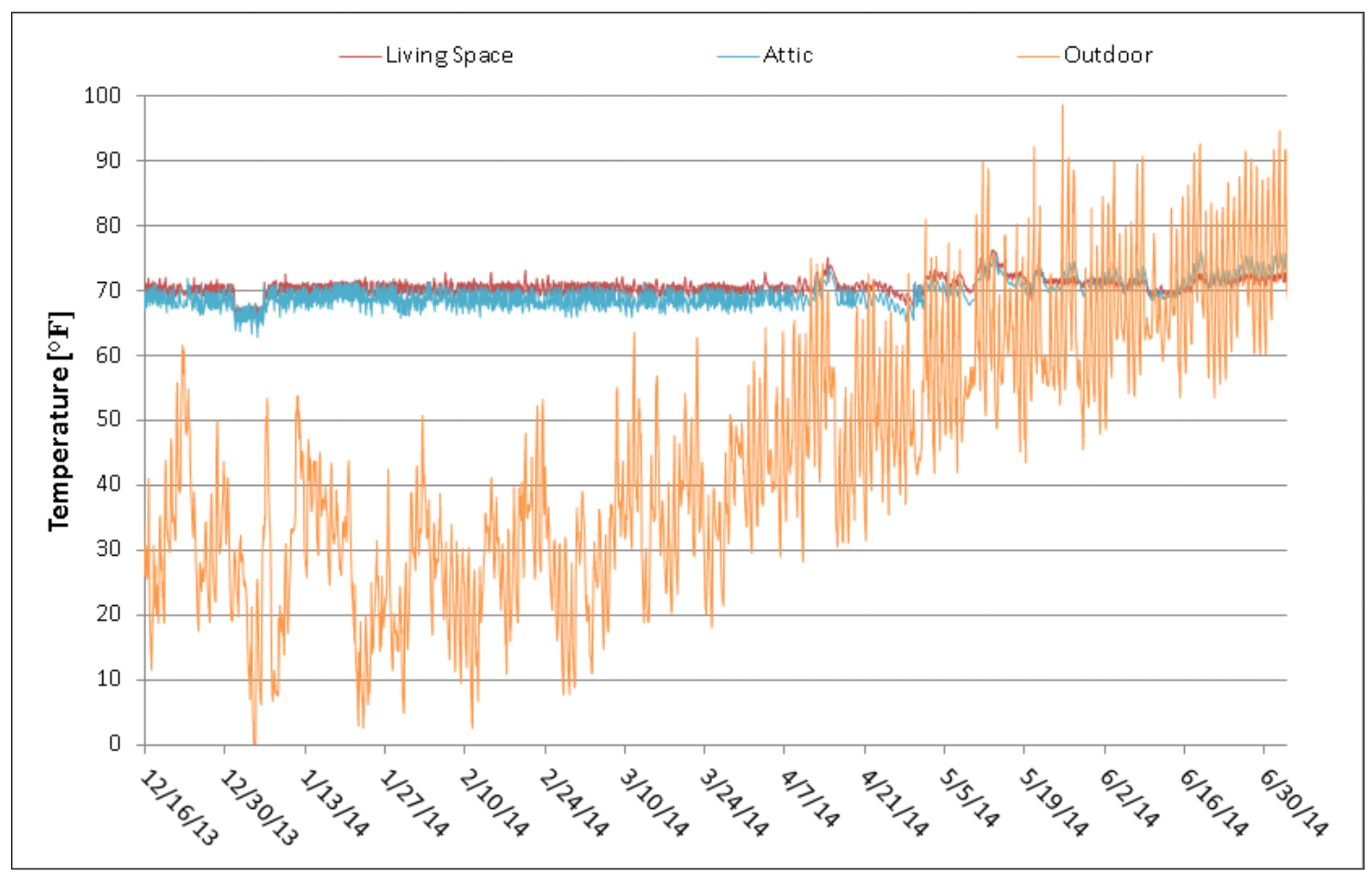

Figure 21. Temperature conditions at House 2 


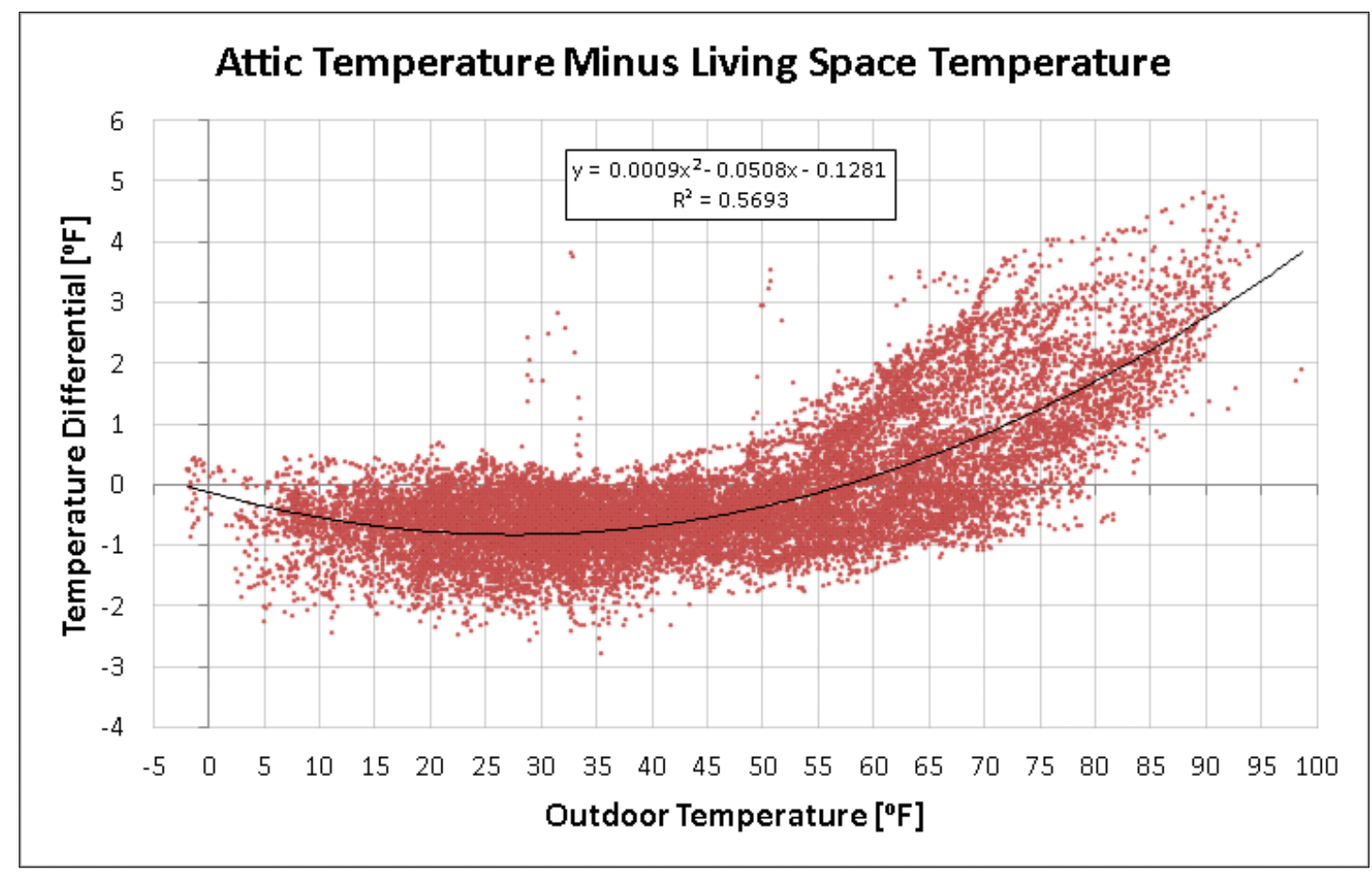

Figure 22. House 2 temperature differential with respect to outdoor temperature

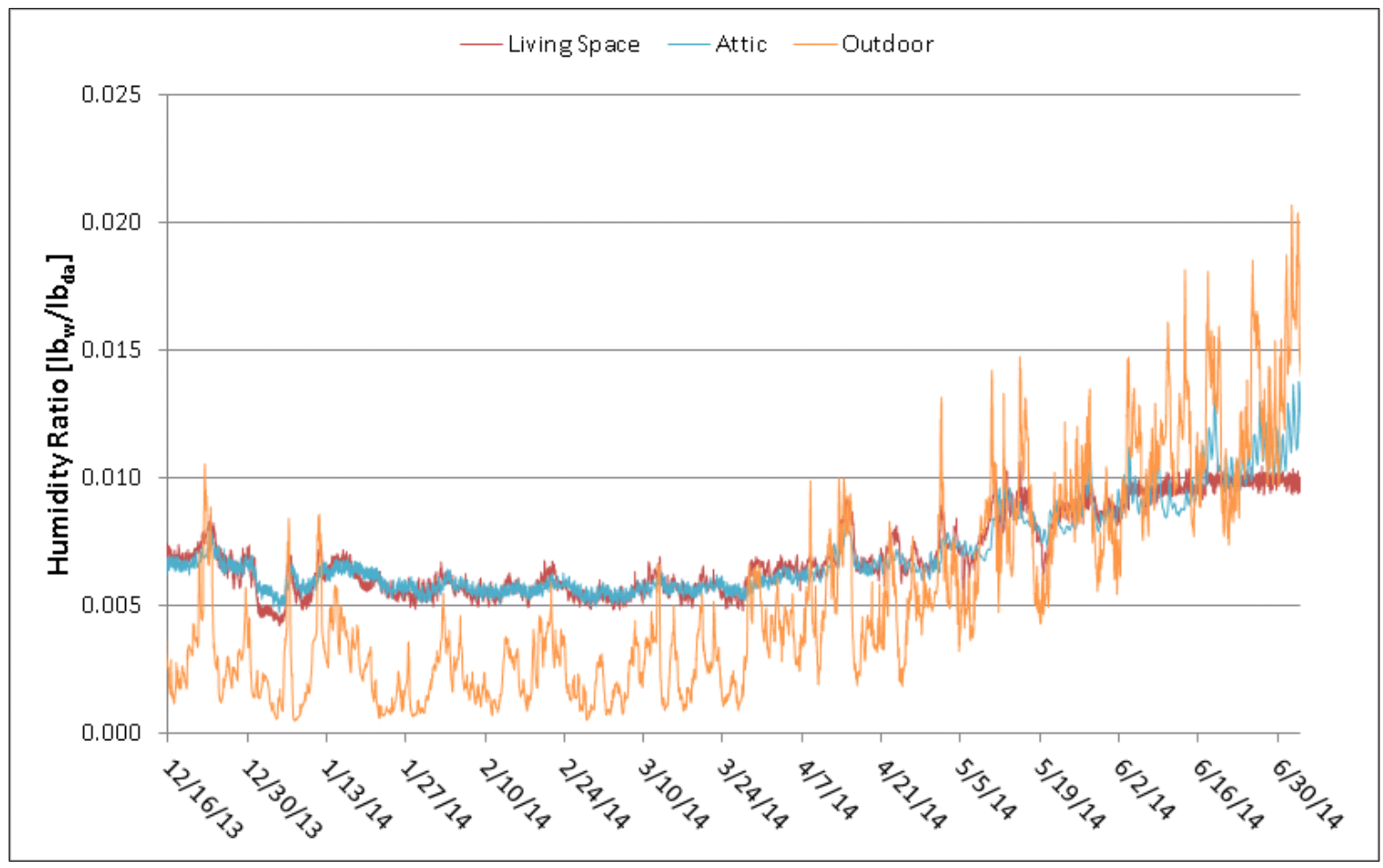

Figure 23. Humidity conditions at House 2 


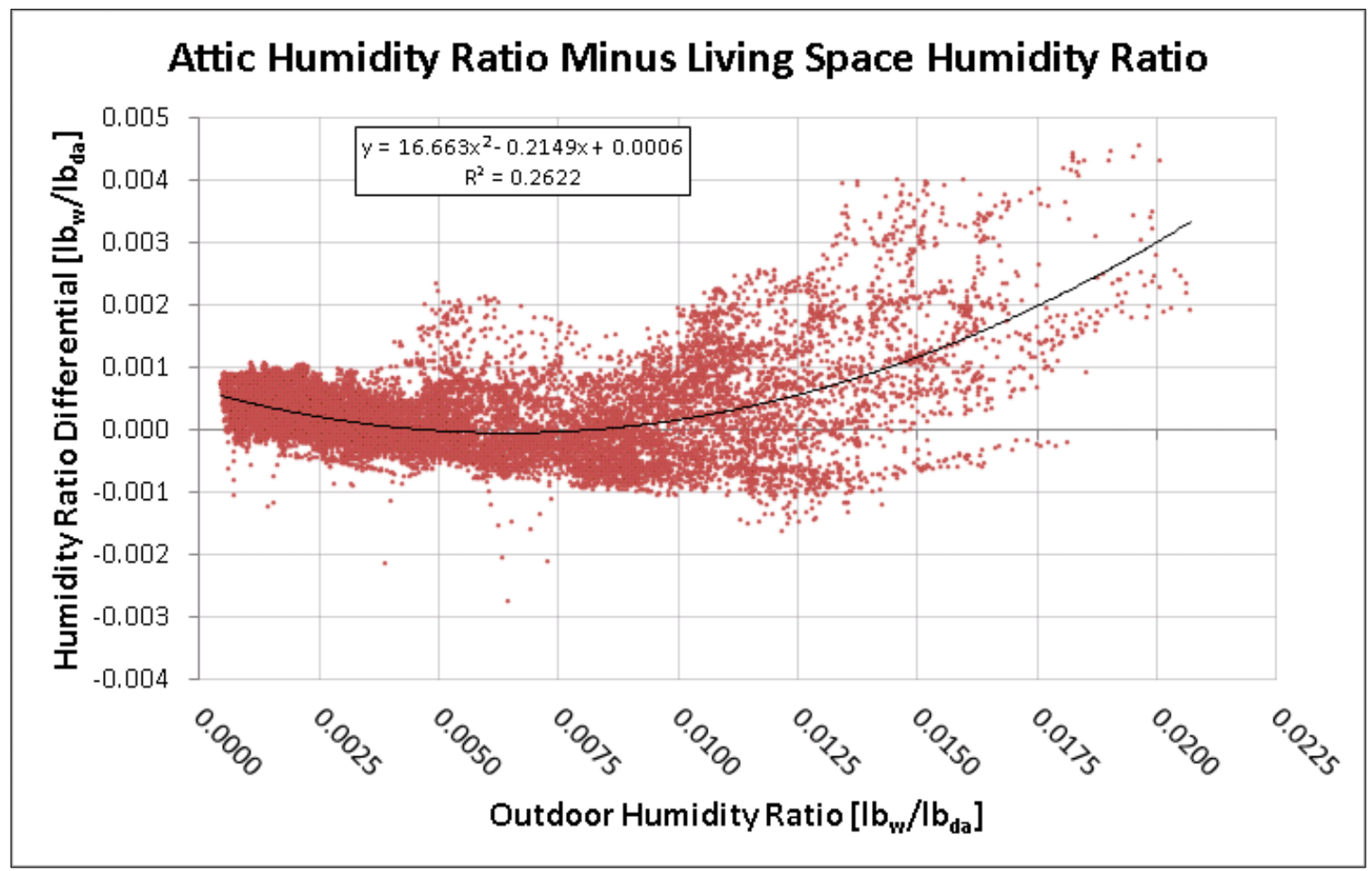

Figure 24. House 2 humidity ratio differential with respect to outdoor humidity ratio

\subsubsection{House 3}

House 3 is a finished attic of a Cape Cod-style house with the monitoring being done in the upper attic, as illustrated in Figure 25. While the upper attic and knee wall attic were the combination of ccSPF against the roof deck and the remainder insulated with ocSPF, the insulated rafter sections were only 5-1/2-in. ocSPF (what was possible during this retrofit without taking down the interior drywall).

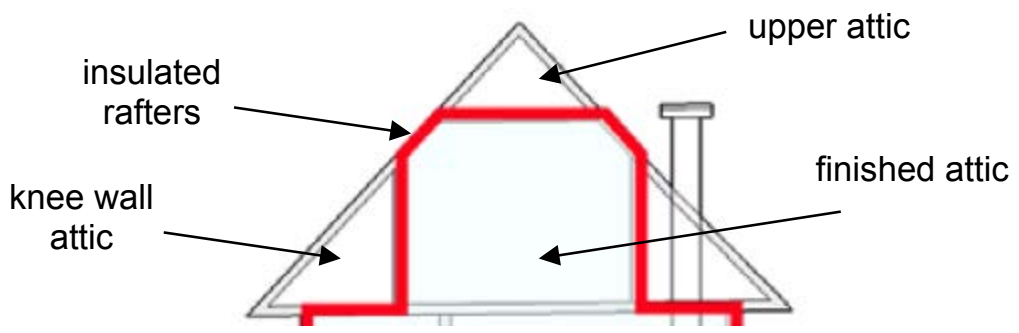

Figure 25. Sketch of House 3 attic

House 3 was monitored from January 2014 through April 2014 only. Figure 26 through Figure 29 show the temperature and humidity ratio conditions at House 3 . While the temperature trends at House 3 were fairly similar to House 1, the swings in living space temperature (between $\sim 62^{\circ} \mathrm{F}$ and $68^{\circ} \mathrm{F}$ during the winter, as seen in Figure 26), lower insulation in the insulated rafter 
space, and higher whole-building leakage likely led to the slightly steeper temperature differential curve with respect to outdoor temperature.

With respect to humidity ratio (Figure 27), while the living space and unvented attic tracked fairly closely throughout the winter, from the spring onward, the attic space saw large spikes in the humidity ratio. In the other two test homes, this fluctuation range in the attic humidity ratio didn't occur until the summer months. The higher perm rating of this insulated rafter roof section may have allowed moisture to invade the upper attic because of solar drive. Alternatively, this could have been a result of the attic being sealed but the exterior walls not being sealed. Humid air could have risen to the unvented attic, and because the sensible cooling load was insufficient to require air conditioning, no dehumidification occurred.

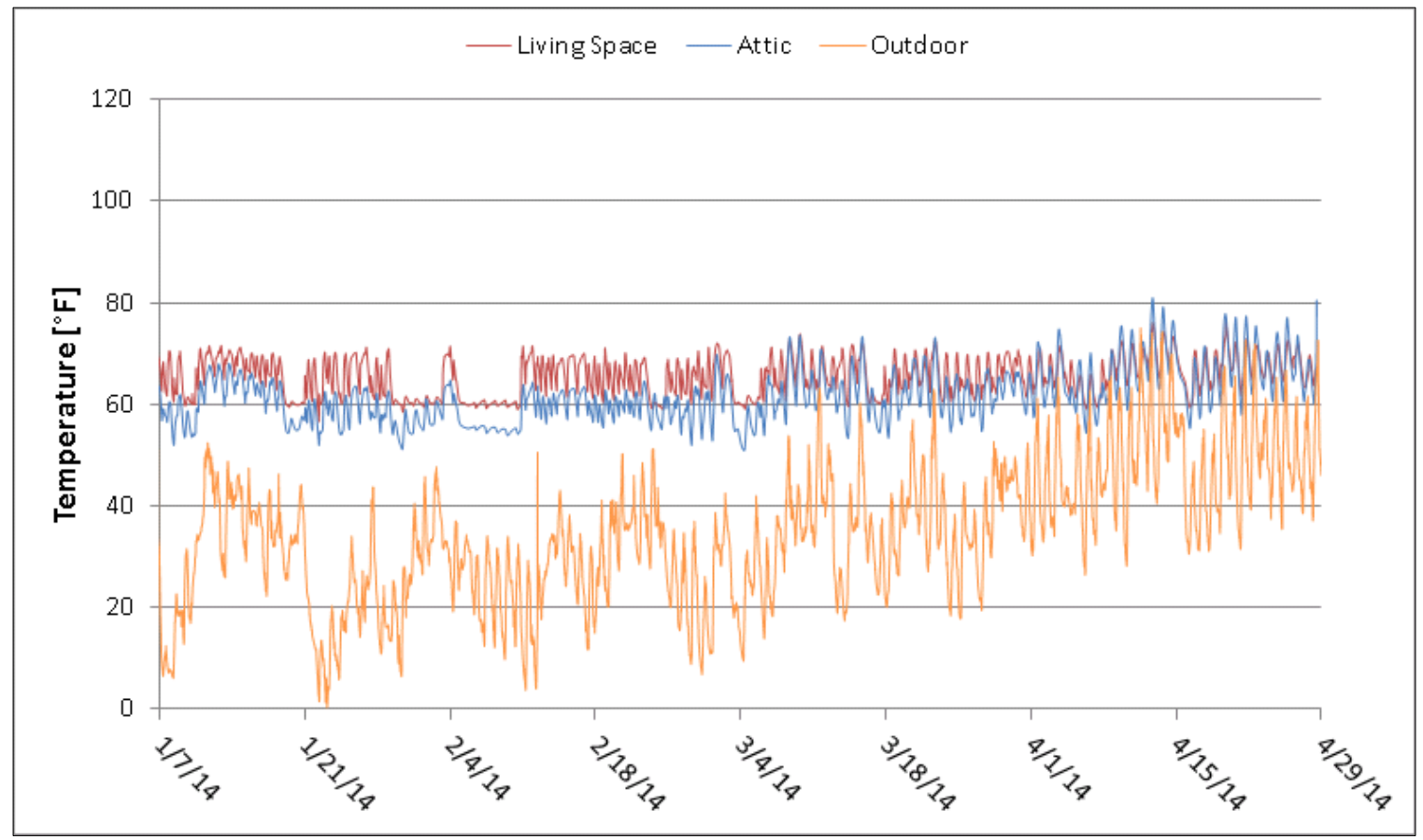

Figure 26. Temperature conditions at House 3 


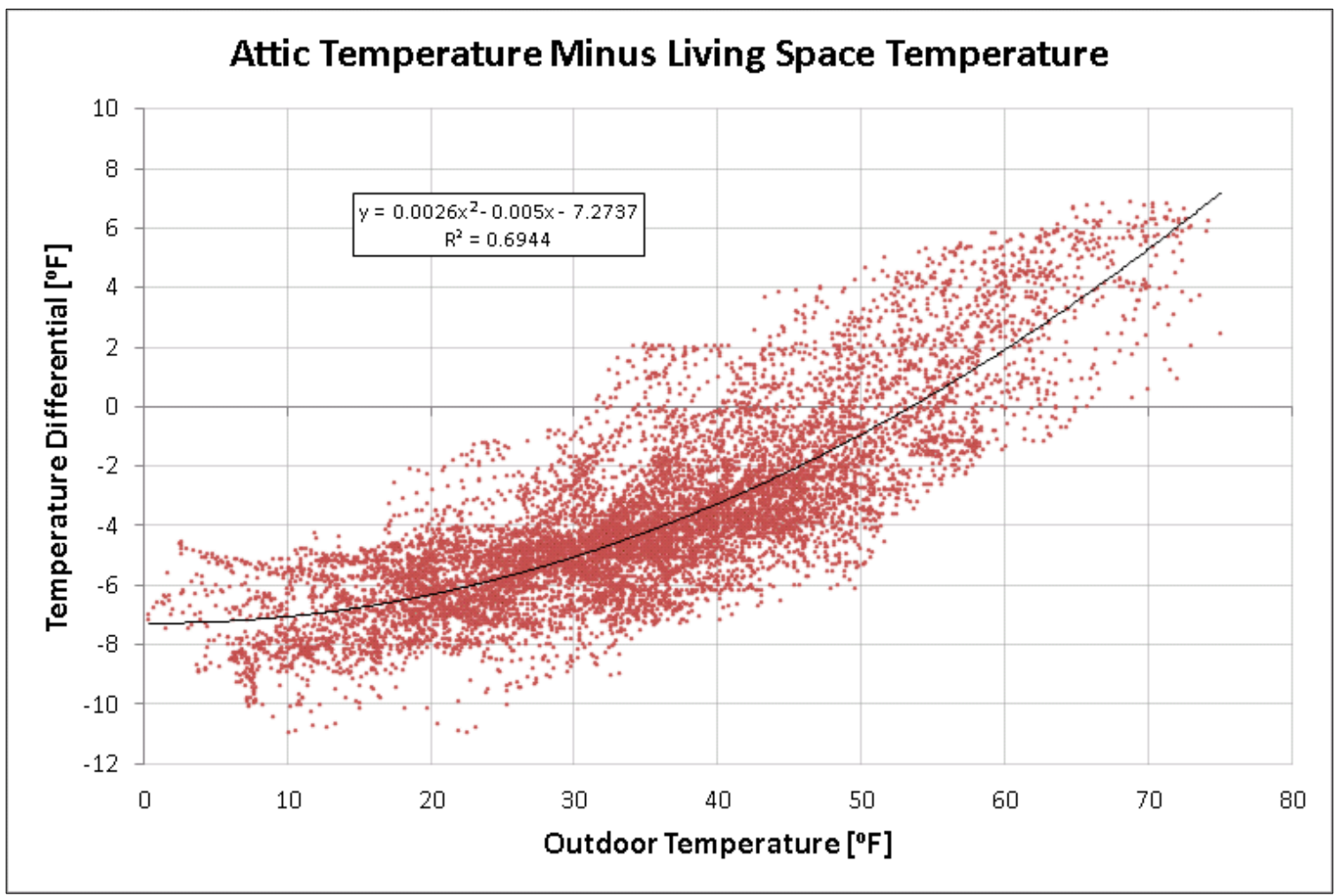

Figure 27. House 3 temperature differential with respect to outdoor temperature

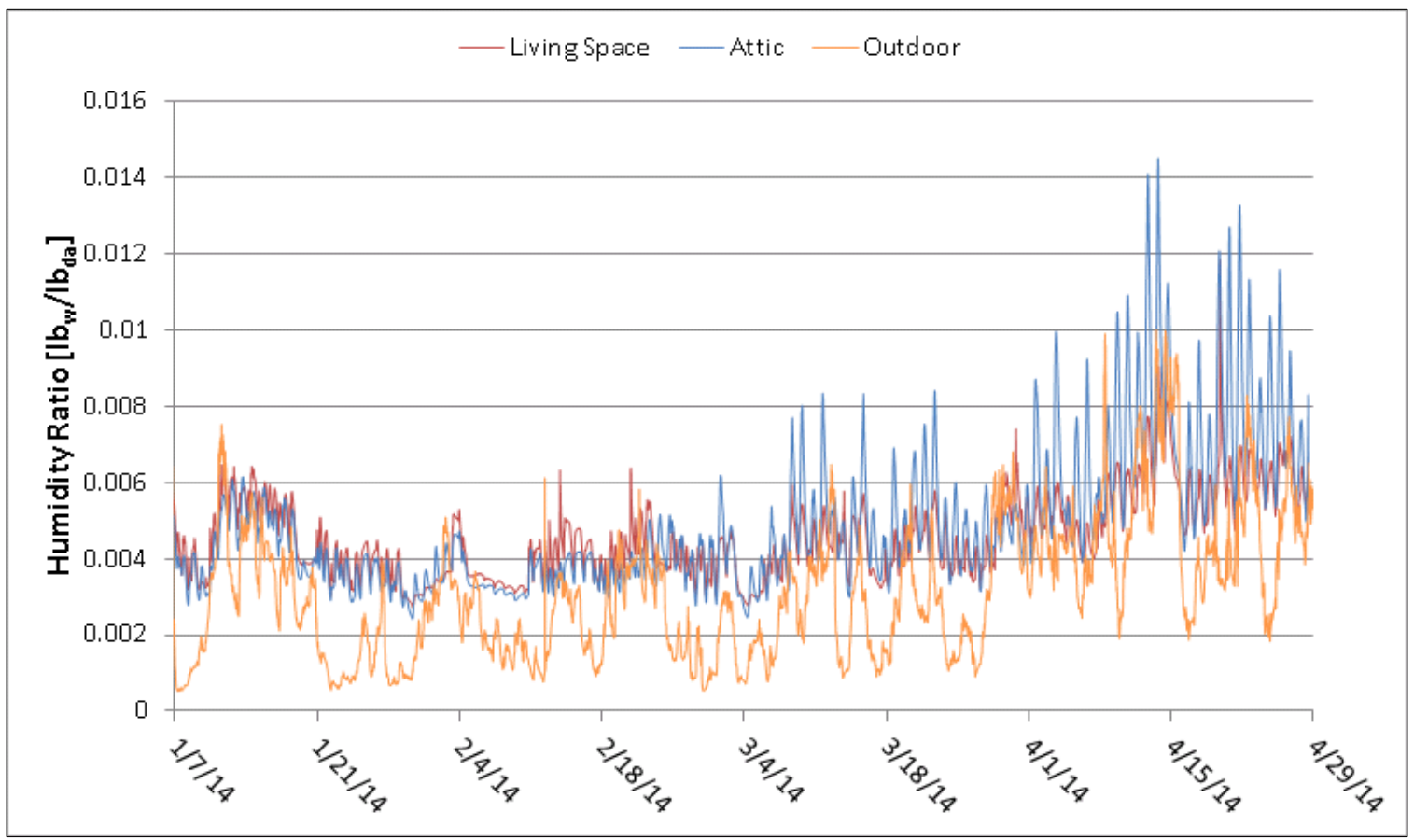

Figure 28. Humidity conditions at House 3 


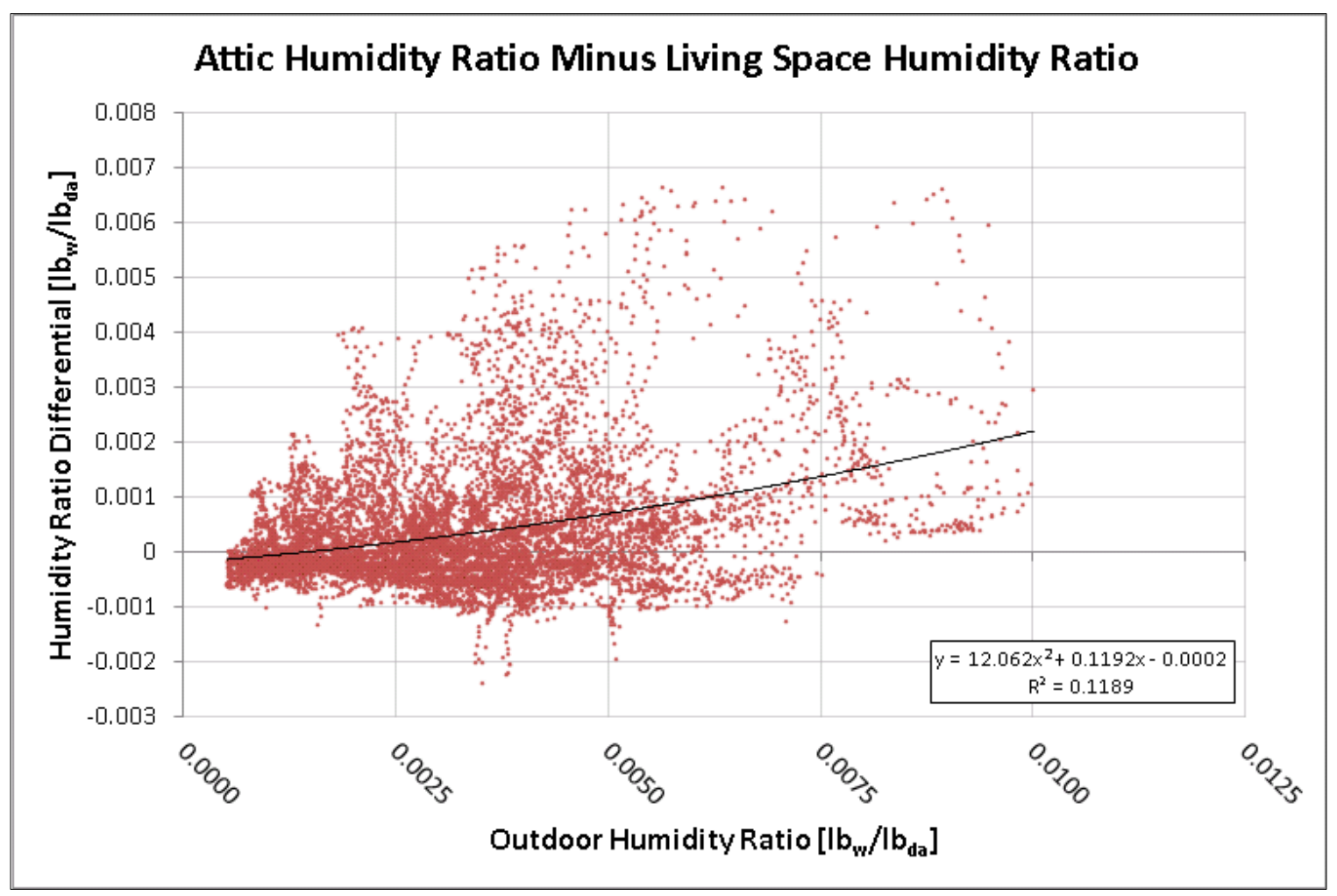

Figure 29. House 3 humidity ratio differential with respect to outdoor humidity ratio 


\section{Discussion}

While this is only a small sample, comparing the results from the three test homes may provide researchers and modelers valuable insight into predicting unvented attic conditions in homes in the Northeast. In Figure 30 and Figure 31, temperature and humidity ratio trends are provided for the three test homes and the BEopt model discussed in Section 1.3. Especially in the case of humidity ratio, the current BEopt modeling assumptions in an unvented attic vary from the three test homes for this climate region.

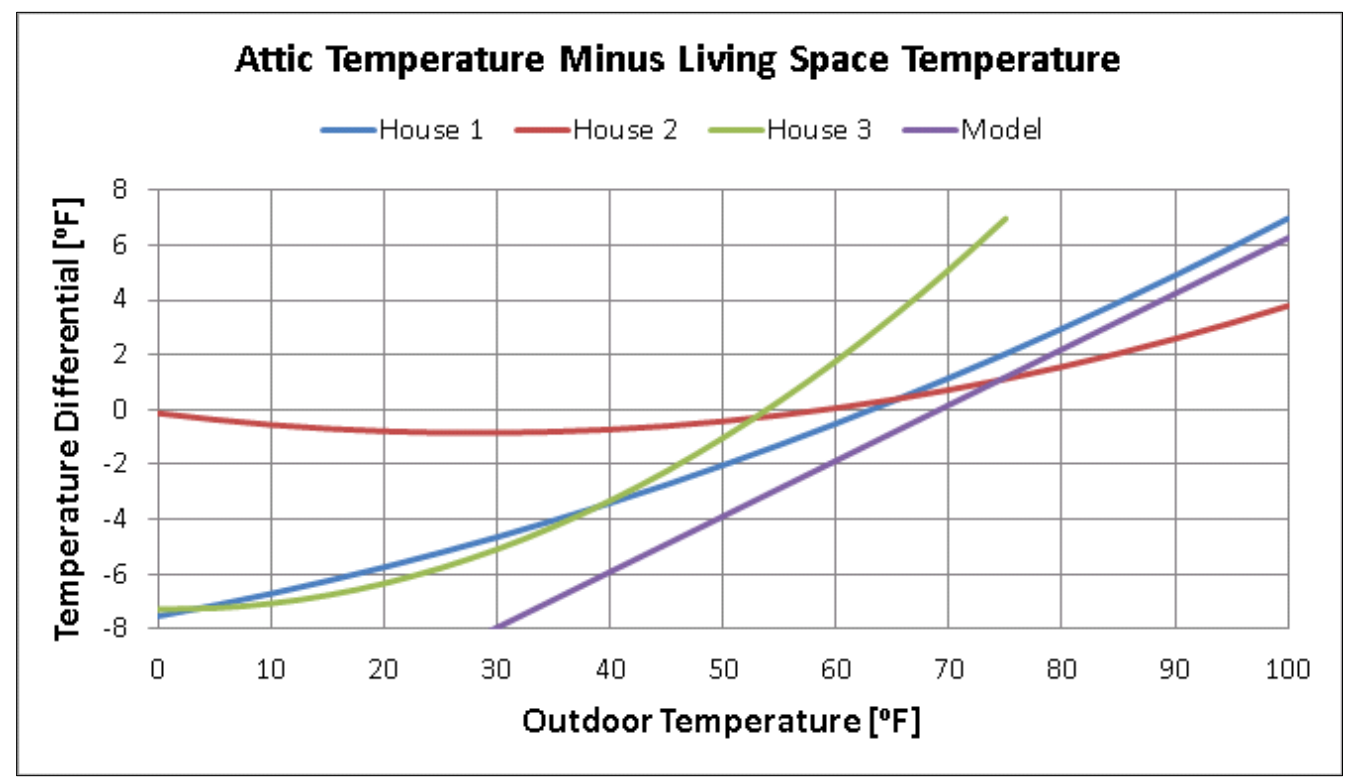

Figure 30. Temperature trend lines for the three test homes and a BEopt model

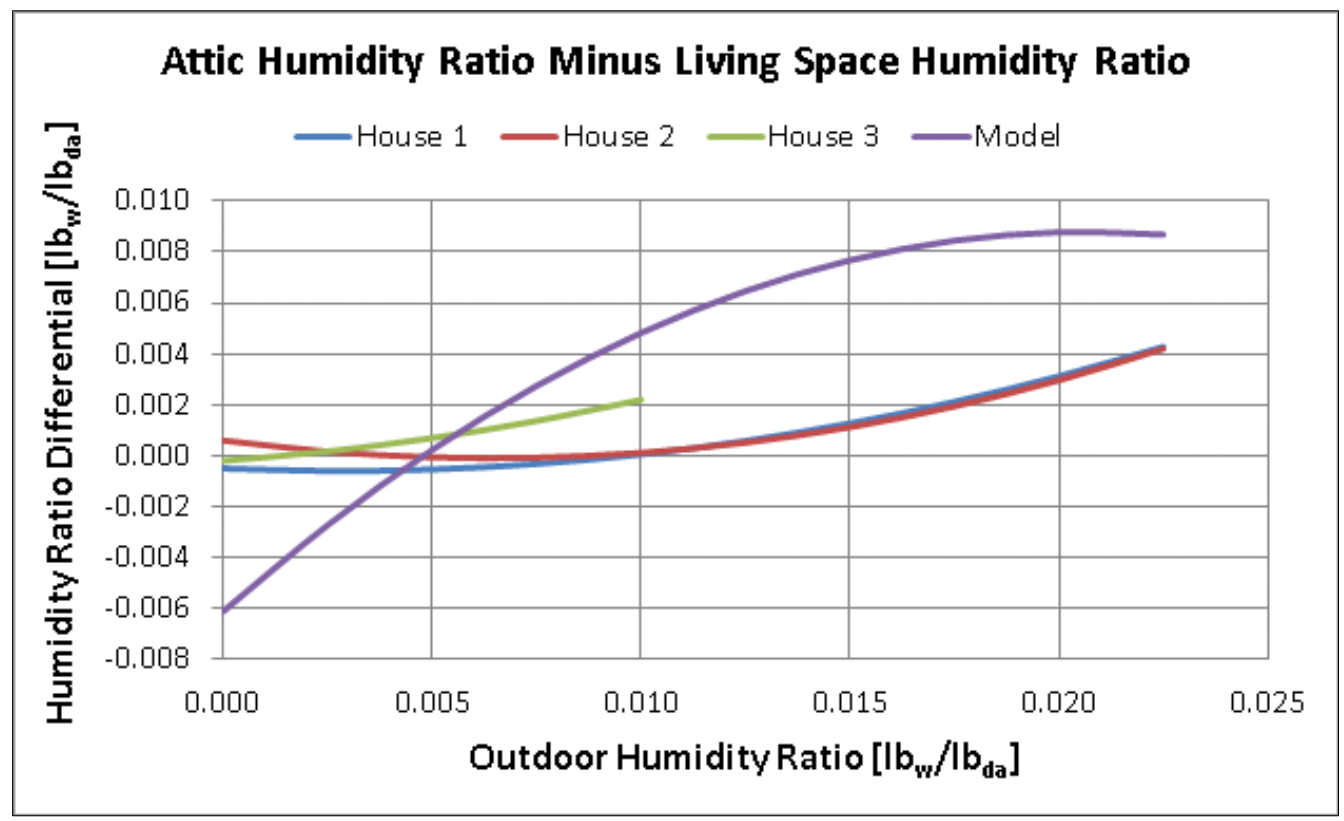

Figure 31. Humidity trend lines for the three test homes and a BEopt model 
Based on this initial field monitoring and assuming an attic-to-living space coupling factor near to 1 , the equations in Table 11 are suggested for estimating attic conditions in the Northeast.

Table 10. Temperature and Humidity Ratio Trends for Various House Types

\begin{tabular}{|c|c|c|}
\hline House Type & $\begin{array}{c}\text { Unvented Attic } \\
\text { Temperature } \\
\left({ }^{\circ} \mathrm{F}\right) \\
\end{array}$ & $\begin{array}{c}\text { Unvented Attic Humidity } \\
\text { Ratio } \\
\text { (lbw/lbda) } \\
\end{array}$ \\
\hline $\begin{array}{l}\text { Energy-Efficient Home } \\
\text { With Ducts in Unvented } \\
\text { Attic (Supply Side } \\
\text { Leakage) }\end{array}$ & $\begin{array}{c}\mathrm{T}_{\mathrm{L}}+0.0009\left(\mathrm{~T}_{\mathrm{OA}}\right)^{2}- \\
0.0508\left(\mathrm{~T}_{\mathrm{OA}}\right)-0.1281\end{array}$ & \multirow{2}{*}{$\begin{array}{l}\mathrm{HR}_{\mathrm{L}}+14.606\left(\mathrm{HR}_{\mathrm{OA}}\right)^{2}- \\
0.1424\left(\mathrm{HR}_{\mathrm{OA}}\right)+0.00005\end{array}$} \\
\hline $\begin{array}{c}\text { Energy-Efficient Home } \\
\text { Without Ducts in } \\
\text { Unvented Attic }\end{array}$ & $\begin{array}{c}\mathrm{T}_{\mathrm{L}}+0.0007\left(\mathrm{~T}_{\mathrm{OA}}\right)^{2}+ \\
0.0751\left(\mathrm{~T}_{\mathrm{OA}}\right)-7.5243\end{array}$ & \\
\hline $\begin{array}{l}\text { Existing Cape Style } \\
\text { Home With Only an } \\
\text { Unvented Attic Upgrade } \\
\text { and No Ducts in Attic }\end{array}$ & $\begin{array}{l}\mathrm{T}_{\mathrm{L}}+0.0026\left(\mathrm{~T}_{\mathrm{OA}}\right)^{2}- \\
0.005\left(\mathrm{~T}_{\mathrm{OA}}\right)-7.2737\end{array}$ & $\begin{array}{c}\mathrm{HR}_{\mathrm{L}}+12.062\left(\mathrm{HR}_{\mathrm{OA}}\right)^{2}+ \\
0.1192\left(\mathrm{HR}_{\mathrm{OA}}\right)-0.0002\end{array}$ \\
\hline
\end{tabular}

* variables: $\mathrm{T}=$ temperature, $\mathrm{HR}=$ humidity ratio

* subscripts: $\mathrm{L}=$ living space, $\mathrm{OA}=$ outdoor air 


\section{Conclusion}

The key research questions for this data collection effort and their answers resulting from the performed experiment were:

\section{Is it appropriate to assume that the unvented attic conditions are the same as the fully conditioned space below?}

The unvented attic is unlikely to be at the same conditions as the living space, unless it is directly or indirectly conditioned. In the case of ducts located in the attic, wintertime conditions of the unvented attic tracked fairly well with the living space conditions. In the summertime conditions, the cooling duct leakage didn't have a noticeable impact on humidity ratio. This is likely because it was primarily supply-side leakage in this study. If the leakage had been on the return side, there might have been the potential for a more noticeable impact on the humidity ratio in the unvented attic.

From a field protocol perspective, a single point measurement in the center of an unvented attic is suitable for characterizing the overall unvented attic conditions.

What interior boundary conditions should be used when modeling unvented roof assemblies, i.e. what are the appropriate attic space temperature and humidity ratio conditions?

While this is only a small sample, comparing the results from the three test homes provides researchers and modelers valuable insight into predicting unvented attic conditions in homes in cold climates. From this limited study, the original modeling assumption of the same conditions for the living space and unvented attic do not appear to be appropriate. Based on this initial field monitoring, and assuming an attic-to-living space coupling factor near to 1, the equations in Table 11 are suggested for estimating attic conditions in the cold climate region.

Table 11. Temperature and Humidity Ratio Trends for Various House Types

\begin{tabular}{|c|c|c|}
\hline House Type & $\begin{array}{l}\text { Unvented Attic } \\
\text { Temperature } \\
\left({ }^{\circ} \mathrm{F}\right)\end{array}$ & $\begin{array}{l}\text { Unvented Attic } \\
\text { Humidity Ratio } \\
\text { (lbw/lbda) }\end{array}$ \\
\hline $\begin{array}{l}\text { Energy-Efficient Home With } \\
\text { Ducts in Unvented Attic (Supply } \\
\text { Side Leakage) }\end{array}$ & $\begin{array}{c}\mathrm{T}_{\mathrm{L}}+0.0009\left(\mathrm{~T}_{\mathrm{OA}}\right)^{2}- \\
0.0508\left(\mathrm{~T}_{\mathrm{OA}}\right)-0.1281\end{array}$ & \multirow{2}{*}{$\begin{array}{l}\mathrm{HR}_{\mathrm{L}}+14.606\left(\mathrm{HR}_{\mathrm{OA}}\right)^{2}- \\
0.1424\left(\mathrm{HR}_{\mathrm{OA}}\right)+0.00005\end{array}$} \\
\hline $\begin{array}{l}\text { Energy-Efficient Home Without } \\
\text { Ducts In Unvented Attic }\end{array}$ & $\begin{array}{c}\mathrm{T}_{\mathrm{L}}+0.0007\left(\mathrm{~T}_{\mathrm{OA}}\right)^{2}+ \\
0.0751\left(\mathrm{~T}_{\mathrm{OA}}\right)-7.5243\end{array}$ & \\
\hline $\begin{array}{l}\text { Existing Cape Style Home With } \\
\text { Only an Unvented Attic Upgrade } \\
\text { and No Ducts in Attic }\end{array}$ & $\begin{array}{l}\mathrm{T}_{\mathrm{L}}+0.0026\left(\mathrm{~T}_{\mathrm{OA}}\right)^{2}- \\
0.005\left(\mathrm{~T}_{\mathrm{OA}}\right)-7.2737\end{array}$ & $\begin{array}{c}\mathrm{HR}_{\mathrm{L}}+12.062\left(\mathrm{HR}_{\mathrm{OA}}\right)^{2}+ \\
0.1192\left(\mathrm{HR}_{\mathrm{OA}}\right)-0.0002\end{array}$ \\
\hline
\end{tabular}

* variables: $\mathrm{T}=$ temperature, $\mathrm{HR}=$ humidity ratio

* subscripts: $\mathrm{L}=$ living space, $\mathrm{OA}=$ outdoor air

What variables have the greatest impact on the difference between the unvented attic and the conditioned space conditions? 
Because this was a small sample set of three homes, all variables were unlikely to be adequately addressed. With that said, the three main variables identified in this data collection study were indirect space conditioning through duct leakage, the building leakage of the living space, and the attic-to-living space coupling factor.

If the unvented attic receives indirect space conditioning from duct leakage, the attic conditions track closer to the living space in terms of temperature. Trends in the humidity ratio didn't seem to be significantly impacted by supply-side duct leakage. If the duct leakage had been on the return side, it would have likely had a greater impact on humidity ratio, but might have minimized the impact on the temperature side.

Because Houses 1 and 2 had similar ACH50 building leakage values and tracked reasonably closely with regard to humidity ratio (while House 3 saw much higher humidity ratios even in the spring months), the building leakage of the living space (all unvented attics were reasonably tight) likely resulted in this difference between the test sites.

While all three test homes were similar in terms of the attic-to-living space coupling factor (0.84-0.89), it makes logical sense that the more connected the two spaces are to each other, the closer they will track in terms of space conditions. This would be confirmed only with additional test sites that have unvented attics, but the ceiling plane has also been air sealed (not typically found in homes). 


\section{References}

Metzger, C.E.; Wilson, E.; Horowitz, S. (2012). Addendum to the Building America House Simulation Protocols. Golden, CO: National Renewable Energy Laboratory. DOE/GO-1020123855. Accessed December 16, 2014: http://www.nrel.gov/docs/fy13osti/57450.pdf.

Schumacher, C. (2007) "Unvented Roof Assemblies for All Climates.” Building Science Digests. BSD-149. April 23, 2007. Accessed May 30, 2014: http://www.buildingscience.com/documents/digests/bsd-149-unvented-roof-assembliesfor-all-climates. 
buildingamerica.gov

\begin{tabular}{l|l} 
u.s. DEPARTMENT OF & Energy Efficiency \&
\end{tabular} ENERCY Renewable Energy 